\title{
Role of extracellular cations in cell motility, polarity, and chemotaxis
}

\author{
This article was published in the following Dove Press journal: \\ Research and Reports in Biology \\ 6 April 201I \\ Number of times this article has been viewed
}

\author{
David R Soll' \\ Deborah Wessels' \\ Daniel F Lusche' \\ Spencer Kuhl' \\ Amanda Scherer' \\ Shawna Grimm ${ }^{1,2}$ \\ 'Monoclonal Antibody Research \\ Institute, Developmental Studies, \\ Hybridoma Bank, Department of \\ Biology, University of lowa, lowa \\ City; ${ }^{2}$ Mercy Medical Center, Surgical \\ Residency Program, Des Moines, \\ lowa, USA
}

\begin{abstract}
The concentration of cations in the aqueous environment of free living organisms and cells within the human body influence motility, shape, and chemotaxis. The role of extracellular cations is usually perceived to be the source for intracellular cations in the process of homeostasis. The role of surface molecules that interact with extracellular cations is believed to be that of channels, transporters, and exchangers. However, the role of $\mathrm{Ca}^{2+}$ as a signal and chemoattractant and the discovery of the $\mathrm{Ca}^{2+}$ receptor have demonstrated that extracellular cations can function as signals at the cell surface, and the plasma membrane molecules they interact with can function as bona fide receptors that activate coupled signal transduction pathways, associated molecules in the plasma membrane, or the cytoskeleton. With this perspective in mind, we have reviewed the cationic composition of aqueous environments of free living cells and cells that move in multicellular organisms, most notably humans, the range of molecules interacting with cations at the cell surface, the concept of a cell surface cation receptor, and the roles extracellular cations and plasma membrane proteins that interact with them play in the regulation of motility, shape, and chemotaxis. Hopefully, the perspective of this review will increase awareness of the roles extracellular cations play and the possibility that many of the plasma membrane proteins that interact with them could also play roles as receptors.
\end{abstract}

Keywords: extracellular cations, chemotaxis, transporters, calcium, receptors

\section{Introduction}

Cations in the aqueous environment play major roles in facilitating cell motility, chemotaxis, and polarity. ${ }^{1-9}$ However, their role is perceived primarily as a source for intracellular cations in the process of homeostasis. Within this conceptual framework, the roles of proteins at the cell surface that interact with extracellular cations have been perceived as primarily that of channels, transporters, or exchangers. The idea that extracellular cations may function as signals at the cell surface, regulating cell behavior and physiology through interactions with coupled receptors, is not generally realized, and when it is, it is limited to $\mathrm{Ca}^{2+} \cdot{ }^{10,11}$ The general perception that the role of extracellular cations is a passive one is rooted in the knowledge first that there are a large number of biochemical reactions and interactions within the cell that depend upon constant, optimum concentrations of particular cations, ${ }^{12-16}$ and second that when cations function as signals, they do so intracellularly. ${ }^{14,17-23}$ Therefore, most experimental biologists prepare solutions for cell and tissue cultures based on recipes sometimes formulated as long ago as 125 years for very specialized purposes, as is the case for Ringer's solution ${ }^{24-30}$ without concern for optimization. ${ }^{4}$
Correspondence: David R Soll

of lowa, lowa City, IA 52246, USA

$\mathrm{Tel}+\mathrm{I} 319335$ III

Fax +I 3193352772

Email david-soll@uiowa.edu 
The idea that extracellular cations may alter cell function by interacting with surface molecules is emerging. It has been demonstrated that $\mathrm{Ca}^{2+}$-binding molecules on the surface of a variety of cell types function as bona fide coupled receptors, ${ }^{10,31,32}$ that specific threshold concentrations of extracellular cations are critical for cell motility, polarity, and chemotaxis, ${ }^{4,5,33,34}$ and that gradients of extracellular cations can direct cell movement through the process of chemotaxis. ${ }^{5,35-50}$ It therefore seems timely that the role of extracellular cations be explored within this new contextual framework.

\section{Cations in environmental niches}

When studying cell behavior in vitro, a scientist should be cognizant of the concentrations of cations in the natural environment to which that cell type has adapted. The ocean, in which life began, has undergone major changes in cation content. Presently, the ocean contains approximately $10 \mathrm{mM}$ $\mathrm{Ca}^{2+}, 55 \mathrm{mM} \mathrm{Mg}^{2+}, 450 \mathrm{mM} \mathrm{Na}^{+}$, and $10 \mathrm{mM} \mathrm{K}^{+}$(Figure 1, Table 1). ${ }^{51-56}$ During the Hadean period, approximately four billion years ago, when thermophilic archaebacteria lived in the ocean, the estimated concentrations of $\mathrm{Ca}^{2+}, \mathrm{Na}^{+}$, and $\mathrm{K}^{+}$ were far lower than they are today (Figure 1). ${ }^{57,58}$ The major soluble anion was $\mathrm{Cl}^{-}$, as it is now. ${ }^{57,58}$ The concentrations of $\mathrm{Ca}^{2+}, \mathrm{Mg}^{2+}$, and $\mathrm{Na}^{+}$increased to their present levels by the Mesoproterozoic era, approximately 1.5 billion years ago, well after the cyanobacteria had evolved and multicellular eukaryotes had appeared (Figures 1A and 1B). This coincided with a change from a reducing to an oxidizing atmosphere (Figures $1 \mathrm{~A}$ and $1 \mathrm{~B}$ ), ${ }^{59}$ a result of photosynthesis by cyanobacteria. ${ }^{58-61}$ When $\mathrm{O}_{2}$ accumulated in the atmosphere, the ocean changed from a "soda ocean" to a "halite ocean", and soluble $\mathrm{Ca}^{2+}$ accumulated due to the reduction in $\mathrm{CO}_{2}$, and hence less $\mathrm{CaCO}_{3}$ precipitation. ${ }^{59}$ Thus, during the evolution of the ocean biota, there was a 200-fold increase in soluble $\mathrm{Ca}^{2+}$, a six-fold increase in $\mathrm{Mg}^{2+}$, and a five-fold increase in $\mathrm{Na}^{+}$(Figure 1).

The changes in the cation concentrations might seem challenging in the evolution of cell surface mechanisms regulating homeostasis, but these changes probably occurred gradually, and in fact may have been far less challenging than the differences that face present day organisms that experience rapid changes in salinity. ${ }^{62}$ Fresh water bodies contain about 10 times less $\mathrm{Ca}^{2+}, 100$ times less $\mathrm{Mg}^{2+}, 1000$ times less $\mathrm{Na}^{+}$, and 100 times less $\mathrm{K}^{+}$than the ocean (Table 1). The Atlantic salmon can move from a fresh water to salt water environment during the parr-smolt transformation, ${ }^{63}$ as a result of developmental changes in the gills that include the expression of transport proteins. ${ }^{64-71}$ Microorganisms and algae in fresh water are commonly faced with dramatic changes in salinity when the water becomes brackish, through evaporation or after rains (Table 1). Some species die when water rapidly becomes brackish, ${ }^{69,70}$ while others adapt rapidly by adjusting their osmotic pressure ${ }^{72}$ through aquaporins, cation transporters, and exchangers. ${ }^{73-76}$

Another major and important environmental niche for free living organisms is soil. ${ }^{51,77-82}$ The concentrations of the major cations in soil are, on average, much higher than in fresh water bodies, but far lower than that in the ocean (Table 1). Cow, pig, and poultry manure, which are often added to farm soil as fertilizers, can be equal to or higher in $\mathrm{Ca}^{2+}$ and $\mathrm{K}^{+}$than seawater, but lower in $\mathrm{Mg}^{2+}$ and $\mathrm{Na}^{+}$ (Table 1). Cow and pig manure can be, on average, far higher in $\mathrm{K}^{+}$and $\mathrm{Na}^{+}$than the soil.

What seems most striking in our survey of aqueous environments is the extreme differences in the concentrations of the major cations (Table 1). Therefore, no single culture solution would fulfill the cationic requirements for all free living organisms. While many experimental scientists have imitated the cationic composition of natural fluid, in many cases, in the interest of expediency, solutions have been substituted that are poor imitations. Most scientists studying salt water organisms have used either filtered or artificial seawater, straying from the natural composition of the ocean only for specific experimental purposes (Table 2). Interestingly, the culture media developed for protozoans such as Tetrahymena and colonial organisms like Volvox can contain $\mathrm{Na}^{+}$concentrations far higher than that in streams and ponds, suggesting that normally these organisms may be better adapted to brackish water at the edges of ponds or soil (Table 2). In the case of Dictyostelium discoideum, a soil amoeba that has been used as a laboratory model for multicellular development and chemotaxis, ${ }^{7,8,83-91}$ common buffer solutions contain $\mathrm{Na}^{+}$and/or $\mathrm{K}^{+}$at concentrations (Table 2) far higher than in fresh water bodies, but in the range found in calcareous soil, manures, and soil fertilized with manure (Table 1), ie, their natural habitats. ${ }^{83,92-98}$ However, the majority of $D$. discoideum media do not contain $\mathrm{Ca}^{2+}$ as an additive, so the final concentration of $\mathrm{Ca}^{2+}$ is usually one order of magnitude below that of soil or manure (Table 2). The compositions of these media have recently been compared for their capacity to support motility and chemotaxis. ${ }^{4}$ Most have been found optimum for chemotactic orientation, but suboptimum for motility. ${ }^{4}$ In culturing chicken and human cells, the most common media that have been developed contain $\mathrm{Ca}^{2+}, \mathrm{Mg}^{2+}$, $\mathrm{Na}^{+}$, and $\mathrm{K}^{+}$at concentrations (Table 2) close to that found in human blood and interstitial fluid (Table 3). ${ }^{24-28,99-102}$ 
A. Cation estimates since the archaebacteria

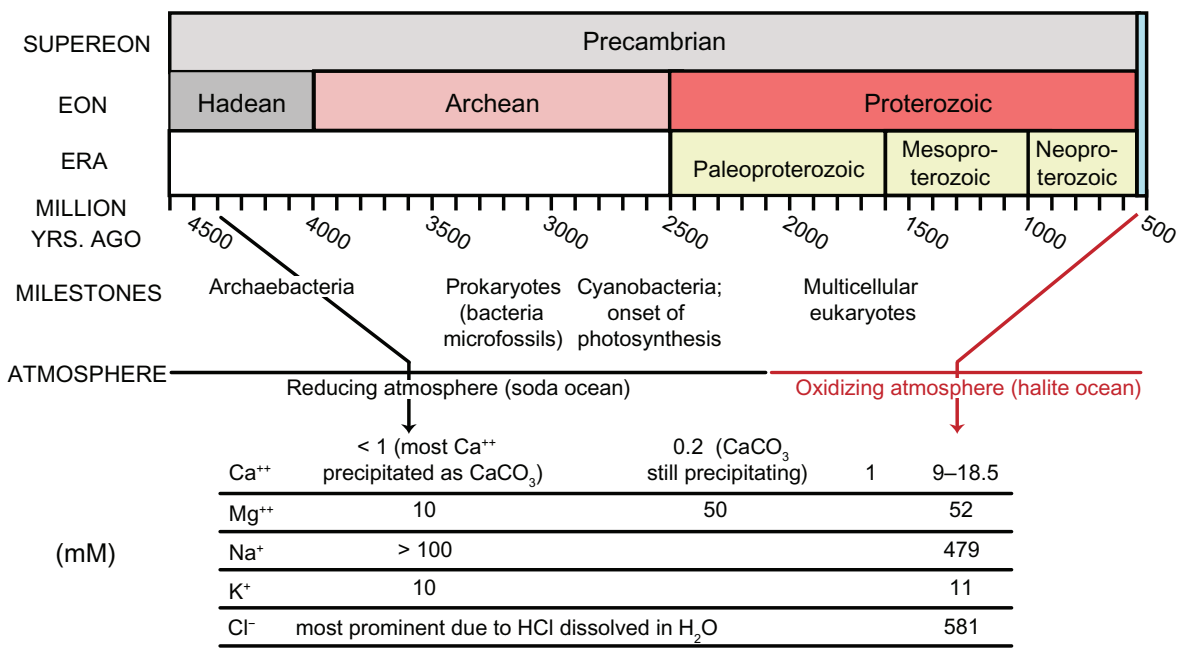

B. Cation estimates during the preceding 500 million years

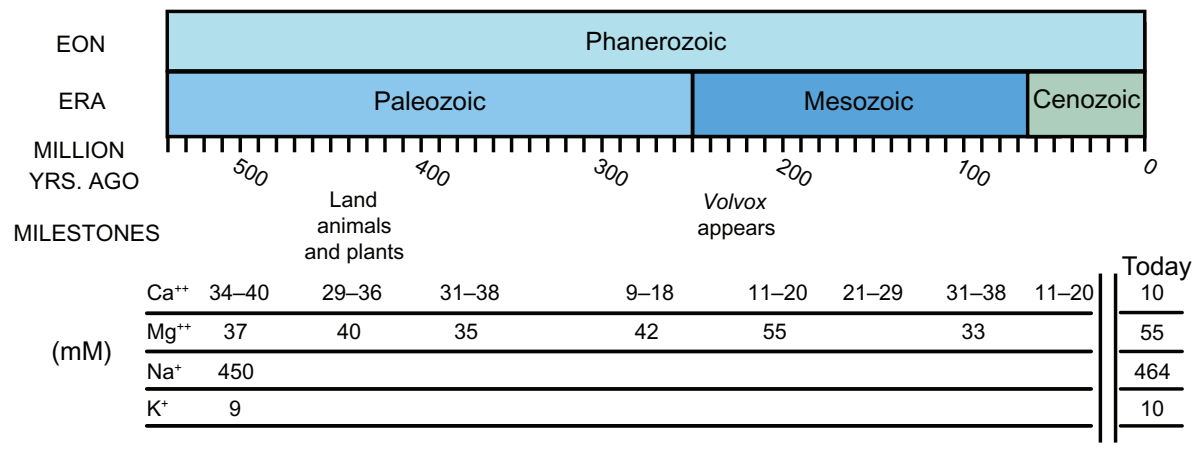

Figure I Estimated concentrations of $\mathrm{Ca}^{2+}, \mathrm{Mg}^{2+}, \mathrm{Na}^{+}$and $\mathrm{K}^{+}$during the evolution of the oceans.

Table I Concentrations of the major soluble cations in sea water, fresh water bodies, drinking water, soil, and manure

\begin{tabular}{|c|c|c|c|c|c|}
\hline Source & $\begin{array}{l}\mathrm{Ca}^{2+} \\
{[\mathrm{mM}]}\end{array}$ & $\begin{array}{l}\mathrm{Mg}^{2+} \\
{[\mathrm{mM}]}\end{array}$ & $\begin{array}{l}\mathrm{Na}^{+} \\
{[\mathrm{mM}]}\end{array}$ & $\begin{array}{l}\mathbf{K}^{+} \\
{[\mathrm{mM}]}\end{array}$ & References \\
\hline Seawater & $9-10.4$ & $55-59$ & $439-464$ & 10 & $5 I-56$ \\
\hline \multicolumn{6}{|l|}{ Fresh water } \\
\hline Lakes & 0.5 & 0.3 & 0.1 & 0.1 & 229,230 \\
\hline Ponds & 0.4 & 0.2 & 0.03 & 0.1 & 231 \\
\hline Rivers $^{\mathrm{a}}$ & 1.8 & 0.8 & 0.5 & 0.1 & 232 \\
\hline \multirow[t]{3}{*}{ Brackish water } & 6.5 & 15 & 90 & n.d. & 233 \\
\hline & 27.5 & 18.1 & 58 & 1.2 & 232 \\
\hline & 5.8 & 5.5 & 43 & 7.7 & 234 \\
\hline lowa City tap water & 0.4 & 0.6 & 0.5 & n.d. & $\begin{array}{l}\text { lowa City Water Division, } \\
2010 \text { (personal communication) }\end{array}$ \\
\hline San Diego tap water & $1.5^{\#}$ & $\sim 1.1$ & $\sim 4.2$ & $\sim 0.12$ & $\begin{array}{l}\text { San Diego, Public Utility } \\
\text { Dept. } 2010 \text { (personal communication) }\end{array}$ \\
\hline Spanish bottled water & $0.01-4.5$ & $0.01-2.9$ & $0.03-47$ & $0.01-1.3$ & 235 \\
\hline \multirow[t]{2}{*}{ Calcareous soil } & 14 & 7 & 29 & I & $78,79,81$ \\
\hline & 12.5 & 3.4 & 1.4 & 1 & 80,236 \\
\hline Cow manure* & $\sim 19$ & $\sim 22$ & 177 & 283 & 237 \\
\hline Poultry manure** & 18 & 6.7 & 0.4 & 1.2 & 238 \\
\hline Pig manure & $\sim 8$ & -3.3 & $\sim 28$ & $\sim 31$ & 239 \\
\hline
\end{tabular}

Notes: aedian of I 109 river sample sites; *Measured at saturation moisture content of the manure; **Determined as change of soil solution due to leaching from manure after surface application $(0-5 \mathrm{~cm})$ compared with control. The authors state in discussion that soluble salts accumulated included substantial amounts of $\mathrm{Ca}^{2+}$ and $\mathrm{Mg}^{2+}$ as well as $\mathrm{K}^{+}$ and $\mathrm{Na}^{+}$, reflecting the generally high basic cation content of the poultry manure used (the content is given as g/kg manure); ${ }^{*}$ reached $3.75 \mathrm{mM}$, as inferred by hardness. ${ }^{240}$ 
Table 2 Concentrations of major soluble cations in commonly used laboratory media

\begin{tabular}{|c|c|c|c|c|c|c|}
\hline Organism & Medium & $\begin{array}{l}\mathrm{Ca}^{2+} \\
{[\mathrm{mM}]}\end{array}$ & $\begin{array}{l}\mathrm{Mg}^{2+} \\
{[\mathrm{mM}]}\end{array}$ & $\begin{array}{l}\mathrm{Na}^{+} \\
{[\mathrm{mM}]}\end{array}$ & $\begin{array}{l}\mathbf{K}^{+} \\
{[\mathrm{mM}]}\end{array}$ & References \\
\hline \multicolumn{7}{|l|}{ Protozoa } \\
\hline \multirow[t]{11}{*}{ Dictyostelium discoideum } & Tricine buffer & - & - & - & 5 & 3,241 \\
\hline & $20 \mathrm{mM} \mathrm{Ca}^{2+}$ solution & 20 & & & 5 & 3 \\
\hline & $40 \mathrm{mM} \mathrm{K}^{+}$solution & - & 2.5 & 5 & 40 & 3,242 \\
\hline & Bonner salts & 2.7 & - & 10 & 10 & 243,244 \\
\hline & Developmental buffer & 0.2 & 2.5 & 15 & - & 245,246 \\
\hline & Sorenson buffer & - & - & 5.4 & 14 & 217,247 \\
\hline & KK2 & 0.1 & 2.5 & - & 24.3 & 248 \\
\hline & Phosphate buffer & - & - & 8 & 7.4 & 249 \\
\hline & Developmental buffer & - & - & 15 & - & 250 \\
\hline & (without divalent cations) & & & & & \\
\hline & Barber buffer & - & - & - & 60 & $|8|$ \\
\hline \multirow[t]{3}{*}{ Tetrahymena pyriformis } & Tetrahymena pyriformis strain & 0.5 & I & 120 & 7.5 & 251,252 \\
\hline & 1630/IW media & & & & & \\
\hline & Mating Type II variety I medium & 0.75 & 0.2 & 0.00001 & 5.7 & 253 \\
\hline \multirow[t]{3}{*}{ Acanthamoeba } & Neff's media & 2 & 0.02 & - & 0.05 & 254 \\
\hline & Amoebae inorganic media & 0.5 & 0.05 & - & 0.43 & 255,256 \\
\hline & Modified Neff's amoeba media & 0.04 & 0.05 & 3.96 & 1 & 257 \\
\hline \multicolumn{7}{|c|}{ Protozoa/Metazoa transition } \\
\hline \multirow[t]{2}{*}{ Volvocales } & Volvocacean media & 0.5 & 0.08 & 2.2 & 0.98 & $258-261$ \\
\hline & $\begin{array}{l}\text { Modified Volvox media } \\
\text { for axenic strains }\end{array}$ & 0.5 & 0.2 & 4.2 & 0.7 & 260 \\
\hline \multicolumn{7}{|l|}{ Metazoa } \\
\hline $\begin{array}{l}\text { Tripneustes gratilla } \\
\text { (sea urchin) }\end{array}$ & Filtered seawater* & $\sim 9.7$ & $\sim 57$ & $\sim 450$ & $\sim 10.1$ & 262 \\
\hline $\begin{array}{l}\text { Stronglyocentrotus purpuratus } \\
\text { (sea urchin) }\end{array}$ & $\begin{array}{l}\text { Calcium and magnesium free } \\
\text { Millipore filtered seawater* }\end{array}$ & 10 added & - & $439-464$ & $10-10.2$ & 263 \\
\hline $\begin{array}{l}\text { Marine culture medium } \\
\text { (phytoplankton, sea urchin) }\end{array}$ & Artificial seawater & 9.3 & 48.3 & 439 & 9 & $264-266$ \\
\hline \multirow[t]{2}{*}{ Xenopus laevis } & Defined oocyte media & 1 & 1 & 48 & 2.5 & 267 \\
\hline & $\begin{array}{l}\text { Roswell Park Memorial Institute } \\
\text { (RPMI)-1640 media }\end{array}$ & 2.3 & 2.7 & $|3|$ & 5 & $100,101,268$ \\
\hline \multirow[t]{2}{*}{ Gallus gallus } & Medium 199 & 1.8 & 0.8 & 143 & 5.4 & 269,270 \\
\hline & Minimum Essential Media (MEM) & 1.8 & 1 & 140 & 5 & $102,27 \mid, 272$ \\
\hline \multirow[t]{7}{*}{ Homo sapiens } & Ringer solution** & 1.25 & - & 136 & 1.3 & 25,273 \\
\hline & Lactated Ringer solution & $\mathrm{I} .4$ & - & 130 & 4 & $25,29,30$ \\
\hline & Medium 199 & 1.8 & 0.8 & 143 & 5.4 & 269,270 \\
\hline & Minimum essential media (MEM) & 1.8 & 1 & 140 & 5 & 102 \\
\hline & Leibovitz media (LM) & 3.5 & 0.8 & 138 & 6 & 274 \\
\hline & $\begin{array}{l}\text { Roswell Park Memorial Institute } \\
\text { (RPMI) media }\end{array}$ & 2.3 & 2.5 & 129 & 5 & 100 \\
\hline & $\begin{array}{l}\text { Roswell Park Memorial Institute } \\
\text { (RPMI)-1640 media }\end{array}$ & 2.3 & 2.7 & $13 \mid$ & 5 & 101 \\
\hline
\end{tabular}

Notes: *Information from Table I; **can only be approximated. ${ }^{273}$

\section{Cations in human fluids}

The most interesting and medically important cationic environments are within the human body. Although the vascular system provides an environment for a host of different cell types, including red blood cells, platelets, white blood cells, and endothelial cells, it is by no means the only extracellular fluid environment. Every organ and cavity contains fluids that act as soluble environments for a number of different cell types. In many cases, the fluids generated by organs are released into other regions of the body or from the body. It should first be realized that, although high in $\mathrm{Na}^{+}$, human blood by no means mimics seawater. Blood (Table 3 ) contains approximately one-fourth the level of $\mathrm{Ca}^{2+}$, one-third the level of $\mathrm{Na}^{+}$, less than half the level of $\mathrm{K}^{+}$, and seventy times less than the level of $\mathrm{Mg}^{2+}$ found in seawater (Table 1). Interstitial fluid, which bathes cells in tissues, mimics the 
Table 3 Concentration of the major soluble cations in extracellular fluids

\begin{tabular}{|c|c|c|c|c|c|}
\hline Extracellular tissue fluid & $\begin{array}{l}\mathrm{Ca}^{2+} \\
{[\mathrm{mM}]}\end{array}$ & $\begin{array}{l}\mathrm{Na}^{+} \\
{[\mathrm{mM}]}\end{array}$ & $\begin{array}{l}\mathrm{Mg}^{2+} \\
{[\mathrm{mM}]}\end{array}$ & $\begin{array}{l}\mathbf{K}^{+} \\
{[\mathrm{mM}]}\end{array}$ & References \\
\hline Blood plasma & 2.5 & 138 & 0.8 & 4.2 & $19,113,275-280$ \\
\hline Interstitial fluid ${ }^{a}$ & 1.2 & 135 & 0.5 & 3.2 & 103 \\
\hline Sweat & 2.5 & $65-82^{\$}$ & $0.2-0.3^{\$}$ & $5-8^{\$}$ & 281,282 \\
\hline Saliva & $0.9-1.6$ & $17-23$ & $0.05-0.1$ & $19.2-19.9$ & 283,284 \\
\hline Pancreatic fluid & $0.1-0.2$ & 140 & $0.1-0.2$ & 5 & 276 \\
\hline Stomach & 0.6 & 68 & 0.7 & 13.4 & 285 \\
\hline Duodenum & $2-6$ & $107-150$ & 0.7 & $4.3-10.9$ & $286-292$ \\
\hline Jejunum & $0.5-8.5$ & 140 & 0.9 & $5-6$ & $276,285,292-294$ \\
\hline lleum & 2.5 & 138 & 0.9 & 6 & 293,294 \\
\hline Bile & 7 & 140 & 3.5 & $5-10$ & 276 \\
\hline Prostatic fluid & 30 & 157 & 16.7 & 66.8 & 295,296 \\
\hline Cerebrospinal fluid & $1.2-1.4$ & 147 & $1.2-3.7$ & $2.7-2.8$ & $114,297,298$ \\
\hline Bone & $2-40 * *$ & 145 & 0.8 & 25 & $104,105,299-301$ \\
\hline Amniotic fluid & $3.6-4.1^{b}$ & $128-134^{b}$ & $0.6-1.4^{b}$ & $3.9-4.6^{b}$ & $302-304$ \\
\hline Scarpa's fluid (endolymph) & 0.02 & 1.3 & 0.63 & 157 & 305,306 \\
\hline Perilymph & 1.3 & 148 & 0.85 & 4.2 & 306,307 \\
\hline Follicular fluid & 1.0 & $|4|$ & 0.7 & 4.6 & 308 \\
\hline Synovial fluid & 2.7 & 110 & 1.0 & 4 & 309,310 \\
\hline Urine* & 5 & 132 & 7 & 25 & 110,311 \\
\hline Milk & 7.5 & 4.7 & $\mathrm{I} .4$ & 15.2 & 312 \\
\hline
\end{tabular}

Notes: a Measured as plasma hemodilution due to change of a position by healthy subjects; ${ }^{b}$ Varies due to time course of gestation; ${ }^{\$}$ Reflects a variation due to exposure (to $100^{\circ} \mathrm{F}$ ) time up to 16 days; *Data depends on nutritional status; **In vivo studies have been performed on human cell lines and on rabbit bone crypts. The range reflects the extracellular calcium concentration at resorbing and nonresorbing sites.

Abbreviation: HUVEC, human umbilical vein endothelial cells.

cationic concentrations in blood (Table 3). ${ }^{103}$ The fluids in other body locations contain cation concentrations generally similar to that of blood, with exceptions (Table 3 ). The cationic contents of spinal fluid, cerebral fluid, synovial fluid, and urine are highly similar to that of blood and interstitial fluid (Table 3). Sweat and saliva, however, have much lower $\mathrm{Na}^{+}$and $\mathrm{Mg}^{2+}$ concentrations, but higher $\mathrm{K}^{+}$concentrations (Table 3). Pancreatic fluid has lower $\mathrm{Ca}^{2+}$ and $\mathrm{Mg}^{2+}$ concentrations, while prostate fluid contains approximately 30 times the $\mathrm{Ca}^{2+}$ concentration, 12 times the $\mathrm{K}^{+}$concentration, and 10 times the $\mathrm{Mg}^{2+}$ concentration of blood (Table 3). Perhaps the most interesting and dramatic cationic fluctuations are those of $\mathrm{Ca}^{2+}$ in regions of bone resorption and formation. The $\mathrm{Ca}^{2+}$ concentration in osteopathic lacunae can rise from 2 to $40 \mathrm{mM}$ during bone resorption in the crypts of the rabbit ear chamber. ${ }^{104-106}$ There is evidence to suggest that similar extracellular fluctuations in $\mathrm{Ca}^{2+}$ concentration occur in humans. ${ }^{107,108}$

In humans, a variety of diseases affect the cation concentrations of body fluids. In patients with hyperkalemia, potassium levels in serum can increase to above $7 \mathrm{mM}$ in severe cases. ${ }^{109}$ The causes of hyperkalemia are varied, including dietary imbalances, rhabdomyolysis (rapid muscle breakdown following severe injury), tumor cell lysis, renal failure, and Addison's disease. ${ }^{109}$ Individuals with prostatitis exhibit reduced levels of $\mathrm{K}^{+}$in their urine and, over time, a rise in prostate fluid. ${ }^{110}$ Individuals can also suffer from hypercalcemia. ${ }^{111}$ Patients with cancer of the parathyroid can have life-threatening concentrations of serum $\mathrm{Ca}^{2+} .{ }^{112}$ The preceding examples represent only a fraction of diseases associated with defects in the regulation of cation concentrations in body fluid. ${ }^{109,110,113-115}$

\section{A bona fide receptor}

The transport classification of the International Union of Biochemistry and Molecular Biology groups channels, transporters, and exchangers into nine classes, each with three or more families (http://www.tcdb.org/). The classification is constantly updated and databases are available to compare transporter protein sequences between or among species and to predict structures ${ }^{116-118}$ (http://www.membranetransport. org/, http://www-abcdb.biotoul.fr/; http://lab.digibench. net/transporter/). No distinction is made in this scheme as to whether a protein is capable of directly sensing extracellular ions ${ }^{4,119}$ and, therefore, may have the potential to activate a signal transduction pathway, the cytoskeleton, or a membrane-associated protein.

Membrane proteins transporting extracellular cations can be activated by an intracellular signal (Figure 2A), a signal from a plasma membrane-associated protein (Figure 2A), 


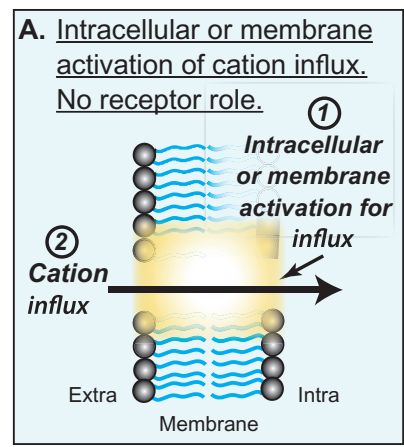

C. Intracellular or membrane activation of cation influx. Extracellular cation activates receptor signaling.
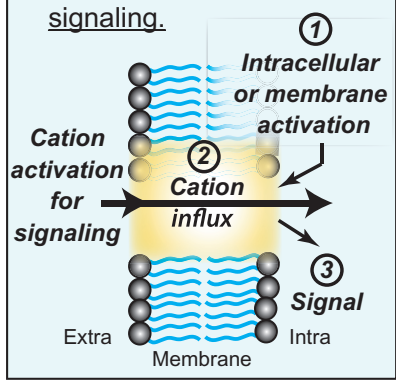

B. Extracellular cation activates cation influx. No receptor role.

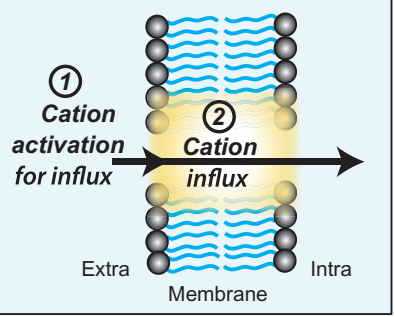

D. Extracellular cation activates influx. Extracellular cation activates receptor signaling.

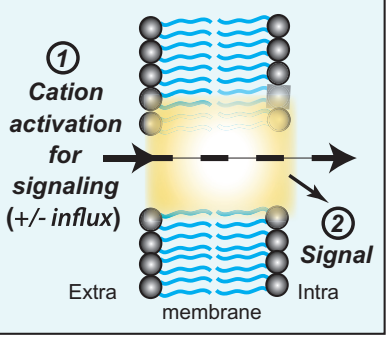

Figure 2 Models of how plasma membrane molecules may or may not function as cation receptors. A) An intracellular or plasma membrane-associated molecule activates the transporter in the plasma membrane, resulting in cation influx. In this case, the cation transporter does not act as a cation receptor for signaling. B) The cation is sensed by the transporter and transported into the cell. In this case, the transporter does not act as a receptor for signaling. C) An intracellular or membrane molecule activates the transporter, resulting in cation influx and cation activation of a signal. In this case, the transporter acts as a receptor for signaling. D) The cation is sensed by the transporter, which may or may not result in influx, but which does result in signaling. In this case, the transporter acts as a receptor for signaling.

or by the extracellular cation (Figure 2B). ${ }^{4,12,18,21,120-125}$ None of these scenarios exclude the possibility that the activated membrane protein, upon interacting with the extracellular cation, then functions as a coupled receptor (Figures $2 \mathrm{C}$ and 2D). To be a bona fide extracellular cation receptor, a molecule must interact at the surface of the cell with a cation and through that interaction directly activate a signal transduction pathway, the cytoskeleton, or a membrane-associated protein (Figure 2). The cation may or may not be transported intracellularly.

\section{A bona fide $\mathrm{Ca}^{2+}$ receptor}

A bona fide $\mathrm{Ca}^{2+}$ receptor (CaR) unrelated to the channels studied earlier in muscle contraction and synapses, ${ }^{126,127}$ was cloned from the parathyroid. ${ }^{31,128} \mathrm{CaR}$ was then identified in a wide array of other cell types. ${ }^{11,32}$ Disease states correlating with mutations in the protein were then identified..$^{47,129-132}$ Although its function can be related to $\mathrm{Ca}^{2+}$ homeostasis, ${ }^{133}$ it is also required for hematopoietic stem cell migration during development ${ }^{36}$ and is involved in chemotaxis in $\mathrm{Ca}^{2+}$ gradients in a variety of cell types, including osteoclasts, ${ }^{43}$ osteoblasts, ${ }^{38,40}$ keratinocytes ${ }^{46}$ gonadotropin-releasing hormone neurons, ${ }^{42,134}$ and monocytes and macrophages. ${ }^{135} \mathrm{CaR}$ appears to be the only family $3 / \mathrm{C} \mathrm{G}$ protein-coupled calcium receptor that can activate signal transduction pathways solely by binding $\mathrm{Ca}^{2+} \cdot{ }^{136} \mathrm{CaR}$ can also modulate the activity of other receptors in the plasma membrane. For example, MacLeod et $a 1^{137}$ showed transactivation of the epidermal growth factor receptor by $\mathrm{CaR}$. In addition, Huang et a ${ }^{138}$ explored the hypothesis that $\mathrm{CaR}$ interacted with other ion channels in the regulation of electrolyte homeostasis. They showed that in human embryonic kidney cells, CaR interacted with two separate but related $\mathrm{K}^{+}$channels, Kir4.1 and Kir4.2, both of which are present along with $\mathrm{CaR}$ in the distal nephron of the kidney. Furthermore, measurements of currents across Xenopus laevis oocyte membranes indicated that interaction of $\mathrm{CaR}$ and $\mathrm{K}^{+}$channels inhibited currents through the latter. Ion flow was restored (ie, not inhibited) in oocytes expressing $\mathrm{CaR}$ mutations that abolished its ability to interact with the $\mathrm{K}^{+}$channels.

Biochemical assays of the properties of $\mathrm{CaR}$ revealed that it is a low affinity receptor, with a $\mathrm{K}_{\mathrm{D}}$ of $4.2-18.8 \mathrm{mM},{ }^{139}$ containing multiple $\mathrm{Ca}^{2+}$ binding sites. ${ }^{140} \mathrm{Mg}^{2+}$ is also an agonist, although less potent. CaRs can also be activated or modulated by stimuli other than $\mathrm{Ca}^{2+}$, including amino acids, polyamines, ${ }^{141}$ polypeptides, and increased $\mathrm{pH},{ }^{142}$ a subject reviewed in Magno et al. ${ }^{133}$

$\mathrm{CaR}$ is a member of the Group II family C G proteincoupled receptors, members of which have seven membrane domains. ${ }^{11}$ The extracellular domains of these receptors form two lobes separated by a cleft $\mathrm{f}^{32,136}$ and hence are referred to as having a venus-fly trap structure that oscillates between an open and a closed state in the absence of ligand. It has been suggested that ligand-binding to both lobes is required to stabilize the trap in the closed conformation to activate the receptor. ${ }^{136}$ The ligand-binding sites of $\mathrm{CaR}$ have not been precisely identified because the crystal structure has not been solved and no direct and quantitative method to measure $\mathrm{Ca}^{2+}$ binding exists. ${ }^{130,133}$ The transmembrane helices of $\mathrm{CaR}$ are linked by intracellular and extracellular loops, as is the case for other members of the G protein-coupled receptor family. ${ }^{97,136,143-145}$ Mutational analyses of the loops of $\mathrm{CaR}$ suggest that the second intracellular loop is required for $\mathrm{G}$ protein-mediated signaling. ${ }^{146} \mathrm{CaR}$ interacts with multiple $\mathrm{G}$ proteins, including $\mathrm{G} \alpha_{1}, \mathrm{G} \alpha_{\mathrm{q},} \mathrm{G} \beta \gamma$, and $\mathrm{G} \alpha_{12 / 13} \cdot{ }^{147-149}$ 
The intracellular carboxy-terminal tail of $\mathrm{CaR}$, which is the least conserved region of the protein, ${ }^{150}$ plays an essential role in phosphoinositide metabolism. ${ }^{138-140}$ Other regions of the tail have been shown to bind a number of additional accessory proteins, including filamin, an actin cross-linking protein. ${ }^{151,152}$

$\mathrm{Ca}^{2+}$ binding to $\mathrm{CaR}$ has been shown to initiate complex downstream pathways. Phospholipase C, ${ }^{143,148}$ phospholipase $\mathrm{A} 2,{ }^{153}$ and phospholipase $\mathrm{D}^{149}$ are activated in some cases, and the synthesis of second messengers, including inositol triphosphate and diacylglycerol, are induced. ${ }^{154}$ Several components of kinase cascade signal transduction pathways can also be activated, including ERK, c-Jun NH2-terminal kinase (JNK), and p38MAPK. ${ }^{155}$ Recently, Boudot et $\mathrm{al}^{43}$ provided evidence that the PI3 kinase/Akt signal transduction pathway is activated by extracellular calcium via $\mathrm{CaR}$ in the osteoclast precursor cell line RAW264.7, and that activation is required for optimal cell migration during $\mathrm{Ca}^{2+}$ chemotaxis. siRNA directed against the $\mathrm{Ca}^{2+}$ sensing receptor abolished phosphorylation of Akt, a PI3 kinase target. In addition, $\mathrm{Ca}^{2+}$-stimulated migration was abolished in RAW264.7 cells expressing a kinase-dead point mutation in Akt. ${ }^{43}$

Therefore, CaR provides the first documented example of a coupled receptor that is directly activated by an extracellular cation, and provides a well established model for testing whether or not other molecules in the plasma membrane function as coupled cation receptors.

\section{$\mathrm{IP}_{3} \mathrm{R}$, another potential $\mathrm{Ca}^{2+}$ receptor}

There is also reason to believe that the inositol triphosphate receptor, $I_{3} R$, may function as a $\mathrm{Ca}^{2+}$ receptor. $\mathrm{IP}_{3} \mathrm{R}$ is a member of a diverse group of cation-permeable channels, ie, the transient receptor potential channels, which can be activated by a variety of stimuli. The first transient receptor potential gene, Drosophila trp, was cloned in $1989^{156}$ following its initial discovery through analysis of a spontaneously occurring photoreceptor mutation. ${ }^{157,158}$ Transient receptor potential channels are now considered a superfamily ${ }^{159}$ defined by sequence homology and topology. ${ }^{160}$ The numerous members of the seven subfamilies vary in regulatory mechanisms ${ }^{161,162}$ as well as cation selectivity. ${ }^{163,164}$ Many members are nonselective cation channels. ${ }^{161}$ As a general rule, transient receptor potential channels are tetrameric structures, each monomer comprised of six transmembrane domains with a pore-associated region between domains 5 and $6 .{ }^{162}$

$\mathrm{IP}_{3} \mathrm{R}$ is usually found in the endoplasmic reticulum, ${ }^{165,166}$ and is not coupled to $\mathrm{G}$ proteins. Both the $\mathrm{COOH}$ and
$\mathrm{NH}_{2}$ termini are cytoplasmic (relative to the endoplasmic reticulum). ${ }^{167-169} \mathrm{IP}_{3} \mathrm{R}$ was demonstrated to be required for $\mathrm{Ca}^{2+}$ release into the cytoplasm from endoplasmic reticulum stores following any signal that elevates its ligand, $\mathrm{IP}_{3}{ }^{170}$ However, $\mathrm{IP}_{3} \mathrm{Rs}$ have also been located in the plasma membrane. ${ }^{168,171-173}$ Subcellular fractionation studies by Rossier et al ${ }^{172}$ implicated actin filaments in maintaining the close association of $\mathrm{IP}_{3} \mathrm{Rs}$ with the plasma membrane. Fadool and Ache ${ }^{173}$ used electrophysiological measurements to describe receptors in the plasma membrane of Panulirus argus olfactory neurons that resembled, but were not identical to, classic $\mathrm{IP}_{3}$ Rs. Dellis et al ${ }^{171}$ used whole-cell recordings in the presence or absence of specific inhibitors to analyze conductance of $\mathrm{IP}_{3} \mathrm{R}$, as well as $\mathrm{IP}_{3} \mathrm{R}$ pore mutants in the plasma membrane of DT40 B cells in response to stimulation of the B cell receptor. They concluded that although a small number of $\mathrm{IP}_{3} \mathrm{Rs}$ were localized in the plasma membrane, they contributed substantially to responses induced by B cell receptor ligand-binding.

In $D$. discoideum chemotaxis, Traynor et al ${ }^{174}$ cloned a gene encoding an $\mathrm{IP}_{3}$-like receptor, IplA. ${ }^{45} \mathrm{Ca}^{2+}$ uptake in response to the chemoattractant cAMP was abolished in an iplA null mutant. However, these cells still underwent chemotaxis in a spatial gradient of cAMP, leading the authors to conclude that intracellular $\mathrm{Ca}^{2+}$ signaling was not essential for cAMP chemotaxis. ${ }^{174}$ Subsequently, Schaloske et al ${ }^{175}$ found that although an agonist-induced $\mathrm{Ca}^{2+}$ entry pathway remained intact in iplA null cells, store-operated calcium entry channels did not function. Fache et al ${ }^{176}$ showed that ipl $A^{-}$cells were defective in calcium stimulated motility under high shear stress conditions, suggesting IplA may be a mechanoreceptor. Recently, it was discovered that in addition to serving as a mechanoreceptor, iplA serves as the receptor for $\mathrm{Ca}^{2+}$ chemotaxis in $D$. discoideum (Lusche et al, in preparation). The recently described $\mathrm{Ca}^{2+}$ chemotaxis system for $D$. discoideum ${ }^{5}$ will be described in a subsequent section of this review.

\section{Other potential $\mathrm{Ca}^{2+}$ receptors}

There are additional plasma membrane proteins with $\mathrm{CaR}$ like characteristics. The neurotransmitter, glutamate, is the ligand for metabotropic glutamate receptors (mGluRs) which are present in the central nervous system. ${ }^{136} \mathrm{~A}$ subset of these receptors (mGluRs 1-8) is also activated by calcium. ${ }^{177,178}$ Tabata and $\mathrm{Kano}^{179}$ reported that sensitivity to glutamate was enhanced by calcium in Purkinje cells. Gamma aminobutyric acid (GABA) B receptors bind the inhibitory neurotransmitter 
GABA. Calcium binds the venus-fly trap domain of these receptors next to the binding site for GABA. ${ }^{180} \mathrm{Ca}^{2+}$ appears to control the affinity of these receptors for GABA. ${ }^{136}$ Therefore, extracellular $\mathrm{Ca}^{2+}$ can directly interact with a receptor to affect activation by a more specific ligand.

\section{Monovalent cation receptors}

Although some monovalent cation channels, transporters, and exchangers may sense extracellular cation concentrations, there has been no demonstration of a bona fide monovalent cation receptor in the plasma membrane for the major ions, $\mathrm{Na}^{+}$and $\mathrm{K}^{+}$. However, there have been hints. For instance, the putative monovalent cation $/ \mathrm{H}^{+}$exchanger, Nhe1, of D. discoideum ${ }^{181}$ mediates enhancement of cAMP chemotaxis by $15 \mathrm{mM} \mathrm{K}^{+}$or $\mathrm{Na}^{+}$, and the facilitation of motility by $40 \mathrm{mM} \mathrm{K}^{+4}$. ClustalW sequence alignment ${ }^{182}$ as well as a Blast search ${ }^{5}$ gave the best alignment with the Nhe8 isoform of a number of other species, including humans. Homologies of domains of Nhe1 to a number of receptors in other species suggested that it may serve as an extracellular $\mathrm{K}^{+}$receptor. $D$. discoideum $\mathrm{Nhe1}$ falls into a family of proteins known to exchange $\mathrm{Na}^{+}$or $\mathrm{K}^{+}$for protons without directly altering membrane potential, ${ }^{119,183,184}$ a characteristic of $\mathrm{G}$ protein-coupled receptors, including those that sense divalent cations. ${ }^{185,186}$ In addition, a search of the Conserved Domain Database revealed that $D$. discoideum Nhe1 contains a KefB domain, ${ }^{4}$ which is known to interact with $\mathrm{K}^{+}$ in a variety of transport proteins. ${ }^{187-190}$ The first 30 amino acids of the N-terminal domain of Nhe1 contain a signal peptide common to the first transmembrane domain of a class of trimeric $\mathrm{G}$ protein-coupled receptors found in higher eukaryotes. ${ }^{191,192}$ A 150 -amino acid region is homologous to a similarly positioned region in a Caenorhabditis elegans family of chemosensory receptors. ${ }^{193,194}$ Finally, Patel and Barber ${ }^{181}$ demonstrated that Nhe1 was localized in the plasma membrane and showed, as Lusche et $\mathrm{al}^{4}$ did subsequently, that the null mutant was defective in polarity, motility, and chemotaxis in buffer solutions containing a concentration of $\mathrm{K}^{+}$that facilitates these attributes in wild-type cells. Most importantly, the $n h e 1^{-}$mutant when compared with its parent strain did not exhibit a major difference in the concentration of cytosolic $\mathrm{H}^{+}$in buffer, ${ }^{181}$ suggesting it may function more as a receptor than as a monovalent cation $/ \mathrm{H}^{+}$ exchanger, although its effect could still be on subtle changes in intracellular $\mathrm{pH} .{ }^{181}$

Examples of monovalent cation channels that may prove to have receptor functions include the P2X-ATP-gated channels, ${ }^{195}$ the ligand-gated ion channels ${ }^{196,197}$ and the glutamate-gated ion channels. ${ }^{198-204}$

\section{Extracellular cations facilitate cell motility and polarity}

Although the concentration of an extracellular cation can increase rapidly in the environment of a cell or form a transient spatial gradient, it is likely that most of the time the concentration is relatively constant, and cells function at an optimal concentration. In support of this hypothesis, in vitro studies of the motility of a variety of cell types have revealed optimum concentrations of key cations, most notably $\mathrm{Ca}^{2+}$, $\mathrm{Na}^{+}$, and $\mathrm{K}^{+}$(Table 4). In studies of the facilitation of motility by $\mathrm{Ca}^{2+}$, the optimum concentrations were found to be 1-10 $\mathrm{mM}$ for cyanobacteria, $9 \mathrm{mM}$ for sea urchin sperm, and 10-20 mM for D. discoideum amoebae (Table 4). These optima may seem high (Table 4), but they are actually within the concentration range of the natural environments of these organisms (Table 1). For a variety of human cells, including bronchial epithelial cells, prostate carcinoma cells, human keratinocytes, human umbilical vein endothelial cells, fibroblasts, and melanoma cells, the optimum concentrations of $\mathrm{Ca}^{2+}$ range between 0.4 and $5 \mathrm{mM}$ (Table 4), a range that encompasses the $\mathrm{Ca}^{2+}$ concentration of blood and interstitial fluid (Table 3). For the motility of murine macrophages and keratinocytes, the optimum $\mathrm{Ca}^{2+}$ concentrations are $1.6 \mathrm{mM}$ and $0.5 \mathrm{mM}$, although one study found the relatively high concentration of $9.2 \mathrm{mM}$ to be optimum for murine fibroblasts (Table 4). The optimum $\mathrm{Mg}^{2+}$ concentrations for a variety of cell types was measured by Grzesiak and Pierschbacher ${ }^{205}$ to be $1.4 \mathrm{mM}$, which is close to the concentrations in blood and interstitial fluid. Therefore, it appears that most human migratory cells require divalent cation concentrations close to that of blood and interstitial fluid for maximum motility. One can only wonder how defective cell motility might be in environments in the body, such as in bile, prostate fluid, areas of bone resorption, and milk, where $\mathrm{Ca}^{2+}$, and in some cases $\mathrm{Mg}^{2+}$, can reach extremely high concentrations (Table 3).

The optimum concentration of monovalent cations is also quite interesting. For ocean cyanobacteria and at least two species of Vibrio, maximum motility is reached at concentrations well below that in the ocean, but motility remains maximum as concentrations are raised higher (Table 4). This suggests that there is tolerance after the optimum concentration is attained. The fact that cyanobacteria are found in all known aquatic environments may explain such tolerance. Perhaps the biggest enigma is that the optimum 
Table 4 Cationic enhancement of cell motility

\begin{tabular}{|c|c|c|c|c|}
\hline Cell type & Cation & $\begin{array}{l}\text { Optimal } \\
\text { concentration }\end{array}$ & Assay & References \\
\hline Human bronchial epithelial cells & $\mathrm{Ca}^{2+}$ & $5 \mathrm{mM}$ & Scratch wound assay & 313 \\
\hline Human keratinocytes & $\mathrm{Ca}^{2+}$ & $1.6 \mathrm{mM}$ & Boyden chamber & 205 \\
\hline HUVEC & $\mathrm{Ca}^{2+}$ & $1.6 \mathrm{mM}$ & Boyden chamber & 205 \\
\hline Human lung fibroblasts & $\mathrm{Ca}^{2+}$ & $1.6 \mathrm{mM}$ & Boyden chamber & 205 \\
\hline Melanoma cells & $\mathrm{Ca}^{2+}$ & $4 \mathrm{mM}$ & Boyden chamber & 314 \\
\hline Murine fibroblasts & $\mathrm{Ca}^{2+}$ & $9.2 \mathrm{mM}$ & Cells filmed in culture flasks & 206 \\
\hline Murine macrophages & $\mathrm{Ca}^{2+}$ & $1.6 \mathrm{mM}$ & Boyden chamber & 205 \\
\hline Murine keratinocytes & $\mathrm{Ca}^{2+}$ & $0.5 \mathrm{mM}$ & Boyden chamber & 46 \\
\hline Sea urchin spermatozoa & $\mathrm{Ca}^{2+}$ & $9 \mathrm{mM}$ & Cells filmed on slides & 315 \\
\hline Cyanobacterium Synechococcus & $\mathrm{Ca}^{2+}$ & $\mathrm{I}-10 \mathrm{mM}$ & Cells filmed on slides & 316 \\
\hline Dictyostelium discoideum & $\mathrm{Ca}^{2+}$ & $10-20 \mathrm{mM}$ & Sykes-Moore perfusion chamber & 3 \\
\hline Human keratinocytes & $\mathrm{Mg}^{2+}$ & $1.4 \mathrm{mM}$ & Boyden chamber & 205 \\
\hline HUVEC & $\mathrm{Mg}^{2+}$ & $1.4 \mathrm{mM}$ & Boyden chamber & 205 \\
\hline Human lung fibroblasts & $\mathrm{Mg}^{2+}$ & $1.4 \mathrm{mM}$ & Boyden chamber & 205 \\
\hline HUVEC & $\mathrm{Mg}^{2+}$ & $0.1 \mathrm{mM}$ & Boyden chamber & 44 \\
\hline Murine macrophages & $\mathrm{Mg}^{2+}$ & $1.4 \mathrm{mM}$ & Boyden chamber & 205 \\
\hline Bovine capillary endothelial cells & $\mathrm{Mg}^{2+}$ & $2.4 \mathrm{mM}$ & Boyden chamber & 317 \\
\hline Murine fibroblasts & $\mathrm{Na}^{+}$ & $56 \mathrm{mM}$ & Cells filmed in culture flasks & 206 \\
\hline Rat spermatozoa & $\mathrm{Na}^{+}$ & $40 \mathrm{mM}$ & Cells filmed on slides & 318 \\
\hline Cyanobacterium Synechococcus strain WH8I I3 & $\mathrm{Na}^{+}$ & $150-250 \mathrm{mM}$ & Cells filmed on slides & 50 \\
\hline Marine species of Vibrio & $\mathrm{Na}^{+}$ & $50 \mathrm{mM}$ & Cells filmed on slides & 319 \\
\hline Vibrio cholerae & $\mathrm{Na}^{+}$ & $200 \mathrm{mM}$ & Cells filmed on slides & 320 \\
\hline Marine species of Halomonas & $\mathrm{Na}^{+}$ & $400 \mathrm{mM}$ & Cells filmed on slides & 321 \\
\hline Melanoma cells & $\mathrm{K}^{+}$ & $30-54 \mathrm{mM}$ & Boyden chamber & 314 \\
\hline Human T cells & $\mathrm{K}^{+}$ & $30 \mathrm{mM}$ & Boyden chamber & 322 \\
\hline Human PMN & $\mathrm{K}^{+}$ & $125 \mathrm{mM}$ & Cells filmed on slides & 323 \\
\hline Murine fibroblasts & $\mathrm{K}^{+}$ & $0.5-73 \mathrm{mM}$ & Cells filmed in culture flasks & 206 \\
\hline
\end{tabular}

Abbreviations: PMN, polymorphonuclear leukocytes; HUVEC, human umbilical vein endothelial cells.

concentration of $\mathrm{K}^{+}$for human cell motility can be 10 times that in blood and interstitial fluid (Table 4). For murine fibroblasts, but not spermatozoa, these high $\mathrm{K}^{+}$optima are close to that for $\mathrm{Na}^{+}$(Table 4). Since the studies to assess $\mathrm{K}^{+}$optima were performed in low $\mathrm{Na}^{+}$, what may have been identified is the optimum for either $\mathrm{Na}^{+}$or $\mathrm{K}^{+}$, cations that can interchangeably interact with surface molecules. This has been demonstrated for the monovalent cation $/ \mathrm{H}^{+}$exchanger Nhe1 in D. discoideum. ${ }^{181}$ Gail et a ${ }^{206}$ demonstrated that although mouse fibroblast motility exhibits high tolerance for extreme changes in the extracellular concentrations of $\mathrm{Na}^{+}$and $\mathrm{K}^{+}$, but requires a more precise optimum $\mathrm{Ca}^{2+}$ concentration, Lusche et $\mathrm{al}^{3,4}$ further demonstrated that the motility of $D$. discoideum could be similarly facilitated by either extracellular $\mathrm{K}^{+}$at $40 \mathrm{mM}$ or $\mathrm{Ca}^{2+}$ at $10-20 \mathrm{mM}$, but through different surface molecules. Hence the optimization of motility can be complex and can be facilitated by different cations with different valances, and through different molecules on the same cell surface.
Many types of animal cells must polarize to translocate at maximum velocity. Hence cell polarization also requires optimum concentrations of cations. Optimum $\mathrm{Ca}^{2+}$ concentrations have been identified for the polarization of D. discoideum amoebae, ${ }^{2-4}$ and human polymorphonuclear leukocytes, ${ }^{207}$ stratification of keratinocytes, ${ }^{208}$ spreading of human umbilical vein endothelial cells,${ }^{44}$ and detachment of intercellular contacts by Madin-Darby canine kidney cells ${ }^{209}$ (Table 5).

\section{Additional transporters that may prove to be receptors}

We have already discussed how the Nhe1 of $D$. discoideum mediates both the $\mathrm{Na}^{+} / \mathrm{K}^{+}$requirement for chemotaxis and the $\mathrm{K}^{+}$requirement for motility and polarity. ${ }^{4}$ There is no clear evidence that Nhe1 performs this role simply as an exchanger, as a receptor, or both. Because $\mathrm{Ca}^{2+}$ can substitute for $\mathrm{K}^{+}$or $\mathrm{Na}^{+}$to facilitate the same cellular changes, ${ }^{3,4}$ and does so through a different cell surface molecule that appears to be a 
Table 5 Cationic regulation of cell shape

\begin{tabular}{llll}
\hline Cell type & Cation & Optimal concentration & Effect \\
\hline Human PMN & $\mathrm{Ca}^{2+}$ & $\mathrm{I}-5 \mathrm{mM}$ & Required for polarization \\
HUVEC & $\mathrm{Ca}^{2+}$ & $\mathrm{I} \mathrm{mM}$ & Reduced spreading of cells \\
Rat osteoclasts & $\mathrm{Ca}^{2+}$ & $20 \mathrm{mM}$ & Reduced cell size \\
MDCK & $\mathrm{Ca}^{2+}$ & $<5 \mathrm{mM}$ & Cells contracted \\
Murine keratinocytes & $\mathrm{Ca}^{2+}$ & $1.2 \mathrm{mM}$ & Required to stratify, keratinize normally \\
Dictyostelium discoideum & $\mathrm{Ca}^{2+}$ & $10 \mathrm{mM}$ & Elongation and suppression of lateral pseudopods \\
MDCK & $\mathrm{Mg}^{2+}$ & $<5 \mathrm{mM}$ & Cells contracted \\
Rat vascular smooth muscle cells & $\mathrm{Mg}^{2+}$ & $1.2 \mathrm{mM}$ & Cells contracted \\
Human PMN & $\mathrm{K}^{+}$ & $125 \mathrm{mM}$ & Induced polarization \\
\hline
\end{tabular}

Abbreviations: PMN, polymorphonuclear; MDCK, Madin-Darby canine kidney; HUVEC, human umbilical vein endothelial cells.

receptor (Lusche et al, in preparation), it has been proposed that Nhe1 acts as a receptor, and that the $\mathrm{Ca}^{2+}$ receptor and Nhe1 function independently upstream of the same signal transduction pathway. ${ }^{4}$ Observations on the channel requirements of neutrophil chemotaxis relate to these observations on $D$. discoideum chemotaxis. Neutrophil chemotaxis to fMLP is dependent upon transient receptor potential and chloride channels, ${ }^{210-213}$ as well as an Nhe channel, ${ }^{214}$ the latter from the same family of which Nhe1 of $D$. discoideum is a member. ${ }^{215}$ Neutrophils respond to the rapid addition of fMLP by an influx of calcium. The rise in cytosolic calcium is necessary for migration. ${ }^{216}$ However, Kindzelskii et $\mathrm{al}^{213}$ also found that the transient receptor potential channels were involved in chemotaxis and localized in lipid rafts at the leading edge in fMLP-stimulated cells. This may be related to the possible formation of $\mathrm{Ca}^{2+}$ gradients in the cytosol of neutrophils undergoing chemotaxis up FMLP gradients. ${ }^{5,35,38,45,213,217}$ Ritter et $\mathrm{al}^{214}$ demonstrated that the addition of an Nhe inhibitor (HOE694, HOE642, or EIPA) disrupted motility during chemotaxis in a Boyden chamber.

deHart et $\mathrm{al}^{218}$ showed that the $\mathrm{K}^{+}$channel, Kir4.2, is involved in the migration of microvascular endothelial cells and mouse embryonic fibroblasts. They showed that GFP$\alpha 9 \beta 1$ integrin colocalized with mCherry-tagged Kir4.2 at focal adhesion sites along the leading edge during migration and that migration could be inhibited by a small hairpin RNA knockdown of Kir4.2. Because the activity of these channels could not be measured during migration, the authors speculated that local $\mathrm{K}^{+}$efflux, mediated by Kir4.2, regulated the rate of migration through integrin-mediated modulation of cell extensions, possibly by inhibition of lateral protrusions. However, colocalization experiments also suggested that the Kir4.2 channel may function as a receptor, interacting directly with integrin at focal adhesion sites.

A last example worth considering is transient receptor potential melastatin 8 (TRPM-8), a channel that primarily mediates $\mathrm{Na}^{+}$and $\mathrm{Ca}^{2+}$ influx. ${ }^{219}$ It is localized apically in epithelial secretory prostate cells. ${ }^{220}$ Because this channel is upregulated in the early stages of prostate cancer and downregulated during progression to the invasive stage, ${ }^{221}$ it has been considered a potential target for new cancer therapies. ${ }^{222}$ Gkika et al, ${ }^{223}$ using whole-cell patch clamp measurements, showed that treatment of human embryonic kidney-TRPM8inducible cells increased $\mathrm{Ca}^{2+}$ entry via activated TRPM-8 channels. In addition, cell surface biotinylation experiments revealed that treatment with prostate serum antigen enhanced the expression of TRPM- 8 channels in the plasma membrane of human embryonic kidney-TRPM8 cells, as well as in cells of the PC3 prostate cancer cell line. Inhibitor studies indicated that prostate serum antigen activated TRPM- 8 via the bradykinin 2 receptor, a classic 7 transmembrane $G$ protein-coupled receptor. Interestingly, migration of PC3 cells was reduced by prostate serum antigen-induced TRPM- 8 activation. The authors concluded that prostate serum antigen activation of TRPM-8 channels may inhibit metastasis in the early stages of cancer, but the gradual loss of TRPM-8 leads to an invasive cellular phenotype. Although, there was no indication that human embryonic kidney-TRPM8 played a role as a receptor, the complexity of the human embryonic kidneyinduced response makes one wonder if TRPM-8 plays a role as a $\mathrm{Ca}^{2+}$ channel receptor as well. Ion channel activity has also been implicated in the progression of numerous other cancers, ${ }^{224}$ including those of the cervix ${ }^{225}$ and brain. ${ }^{226}$ The correct experiments to test this hypothesis have not been performed, given the pervasive assumption that the role of channels, transporters, and exchangers is solely to move cations in or out of cells.

\section{Chemotaxis in cation gradients}

In previous sections of the review, we have focused primarily on the "global" effects of extracellular cations on cell behavior. However, cations can form soluble gradients 
through diffusion if released from a source. Although we have very little direct proof for the generality of such gradients, their existence has been demonstrated in such events as bone resorption, in which the release of $\mathrm{Ca}^{2+}$ has been measured. ${ }^{104}$ We can also speculate on their existence by the behavior of cells in cation gradients generated in vitro. Here, we review the literature on the possible role of chemotaxis up cation gradients, primarily $\mathrm{Ca}^{2+}$ gradients, during development, tissue maintenance, angiogenesis, disease states, and D. discoideum aggregation.

\section{Development}

$\mathrm{Ca}^{2+}$ chemotaxis has been implicated in the homing of newly formed immune cells. Hematopoietic stem cells give rise to cells of both myeloid and lymphoid lineages in the fetal liver. Hematopoietic stem cells then migrate from the fetal liver to the bone marrow, where they reside in the endosteal niche, an area of active bone remodeling. The expression of $\mathrm{CaR}$ on the surface of murine hematopoietic stem cells was confirmed by flow cytometry and by reverse transcription-polymerase chain reaction, lending support to the idea that extracellular $\mathrm{Ca}^{2+}$ played a role in targeting of hematopoietic stem cells. ${ }^{36}$ Histological analyses revealed a striking absence of hematopoietic stem cells in $\mathrm{CaR}^{-/-}$mice. ${ }^{36}$ Hematopoietic stem cells from $\mathrm{CaR}^{-/-}$mice engrafted into irradiated wild-type mice failed to migrate to the endosteal niche. These studies suggested that the defect was due to an inability of the $\mathrm{CaR}^{-/}$hematopoietic stem cells to detect extracellular $\mathrm{Ca}^{2+}$ gradients.

$\mathrm{Ca}^{2+}$ also acts as a possible second chemoattractant in the migration of gonadotropin-releasing hormone neurons from their point of origin in the anterior nasal compartment to the hypothalamus during development. The role of $\mathrm{Ca}^{2+}$ gradients was studied in vitro using olfactory-derived (GN11) and hypothalamus-derived (GT1-7) murine cell lines. ${ }^{42}$ Cells of both lines chemotaxed up $\mathrm{Ca}^{2+}$ gradients in Boyden chambers. Both cell lines also underwent chemotaxis up gradients of the monocyte chemoattractant protein-1. Elevated levels of $\mathrm{Ca}^{2+}$ induced the production of monocyte chemoattractant protein-1 in GT1-7 cells, but not in GN11 cells, indicating that extracellular $\mathrm{Ca}^{2+}$ may promote gonadotropin-releasing hormone neuronal migration to the hypothalamus through several mechanisms. The $\mathrm{Ca}^{2+}$ effects appear to be $\mathrm{CaR}$ mediated, because both chemotaxis and the increased production of monocyte chemoattractant protein-1 in high $\mathrm{Ca}^{2+}$ were attenuated in cells expressing a dominant-negative form of CaR. Numerous, less detailed observations on the effects of $\mathrm{Ca}^{2+}$ and other cations on motility and chemotaxis during development, suggest that cation chemotaxis may indeed play a more general role and this role may involve cation receptors.

\section{Tissue maintenance}

The process of bone remodeling, which is a balance between bone resorption and bone formation, is carried out by osteoclasts and osteoblasts, respectively. It is one of the most interesting examples of cationic chemotaxis. Osteoclast precursors, which are mononuclear cells recruited from the circulation, enter the bone and fuse to form multinucleated osteoclasts that degrade bone. The concentration of extracellular $\mathrm{Ca}^{2+}$ in the area of bone resorption reaches $40 \mathrm{mM}$. A murine mononuclear osteoclast precursor cell line was used as a model to determine if $\mathrm{Ca}^{2+}$ gradients attract mononuclear cells to the bone. ${ }^{43}$ Boyden chamber assays revealed that the osteoclast precursor cells migrate up $\mathrm{Ca}^{2+}$ gradients. The chemotactic effect of $\mathrm{Ca}^{2+}$ is mediated through $\mathrm{CaR}$, because migration is inhibited when siRNA is used to knock down $\mathrm{CaR}$ expression. ${ }^{43} \mathrm{~A}$ murine osteoblast-like cell line, also expressing $\mathrm{CaR}$, undergoes chemotaxis in a $\mathrm{Ca}^{2+}$ gradient. ${ }^{38,40}$ This story would obviously be complete if both a $\mathrm{Ca}^{2+}$ gradient and migrating cells could be visualized simultaneously in vivo, but a refined method for performing this has not been developed to date.

The homing of immune cells to sites of injury and infection is an essential part of the host defense response, a process generally attributed to the induction of cell migration by gradients of chemokines. Extracellular fluids at these sites have been reported to have elevated levels of $\mathrm{Ca}^{2+}$.227,228 Human monocytes express CaR. Monocytes chemotax up $\mathrm{Ca}^{2+}$ gradients, ${ }^{39}$ and chemotaxis is enhanced in combined gradients of monocyte chemotactic protein- 1 and $\mathrm{Ca}^{2+}$, indicating that $\mathrm{Ca}^{2+}$ gradients may function alongside chemokine gradients to enhance the chemotactic response. These results were confirmed by in vivo studies where mice were injected at homing sites with $5 \mathrm{mM} \mathrm{Ca}{ }^{2+}$, monocyte chemotactic protein-1, or a combination of both, and monocyte infiltration was quantified by immunostaining of tissue sections. ${ }^{39}$

$\mathrm{Ca}^{2+}$ chemotaxis has also been implicated in angiogenesis. This process is important in the progression of wound healing, tissue remodeling, and tumor formation. Multiple cell types are involved in this process, including endothelial progenitor cells from blood and bone marrow, which possess stem cell-like qualities similar to those of hematopoietic stem cells. ${ }^{35}$ Because extracellular $\mathrm{Ca}^{2+}$ regulates homing of hematopoietic stem cells to endosteal niches, ${ }^{36}$ Aguirre et al ${ }^{35}$ investigated the effects of extracellular $\mathrm{Ca}^{2+}$ on endothelial progenitor cells derived from rat bone marrow. Expression 
of $\mathrm{CaR}$ on the surface of endothelial progenitor cells was demonstrated by immunofluorescent staining with two antibodies against different receptor epitopes. Endothelial progenitor cells underwent chemotaxis in a gradient of extracellular $\mathrm{Ca}^{2+}$. Lapidos et $\mathrm{al}^{44}$ also reported that human umbilical vein endothelial cells underwent chemotaxis in $\mathrm{Mg}^{2+}$ gradients. At the lower concentration of $0.1 \mathrm{mM}$, $\mathrm{Mg}^{2+}$ had a chemokinetic effect. It is unclear why similar effects were not observed for $\mathrm{Ca}^{2+}$ in this particular study, given that others have reported that human umbilical vein endothelial cells exhibit increased motility when stimulated with millimolar concentrations of $\mathrm{Ca}^{2+}$ in the range of those measured in wound fluid, ${ }^{205}$ and both $\mathrm{Ca}^{2+}$ and $\mathrm{Mg}^{2+}$ levels increase after wounding. These few examples suggest that cation gradients and cation receptors may play roles in other aspects of tissue maintenance.

\section{Disease states}

Recently it was demonstrated that $\mathrm{Ca}^{2+}$ may be involved in macrophage chemotaxis. ${ }^{135}$ When tested in $\mathrm{Ca}^{2+}$ gradients in Boyden chambers, macrophages and macrophage-derived foam cells, the lipid-sequestering cells found in atherosclerotic plaques, underwent chemotaxis, but $\mathrm{Ca}^{2+}$ concentrations in the source of a Boyden chamber higher than $1 \mathrm{mM}$ inhibited cell motility. This is lower than the normal range for $\mathrm{Ca}^{2+}$ chemotaxis in Boyden chambers (Table 6). These results suggest that high calcium might generate gradients to recruit macrophages and foam cells to the developing lesions, but once the cells migrate into a lesion, the high $\mathrm{Ca}^{2+}$ concentration suppresses motility, leading to the retention of those cells in the atherosclerotic plaque.

Cationic chemotaxis has also been implicated in cancer metastasis. Breast cancer cells have a propensity to metastasize to bone. This preference is believed to be due to the release of several chemotactic factors during bone resorption, one of which is $\mathrm{Ca}^{2+}$. Saidak et $\mathrm{al}^{47}$ found that, in Boyden chamber assays, cells of the highly metastatic line, MDA-MB-231, exhibited a strong chemotactic response to $\mathrm{Ca}^{2+}$, cells of the moderately metastatic lines, MCF7 and T47D, exhibited a more moderate response, while cells of the nonmetastatic line, BT474, cells did not respond. ${ }^{47}$ Knockdown of CaR by siRNA inhibited chemotaxis up $\mathrm{Ca}^{2+}$ gradients in the responding cell lines. Because CaR was expressed in all of the cell lines, the authors concluded that CaR was necessary, but not sufficient, for $\mathrm{Ca}^{2+}$ chemotaxis, and that additional factors were at play. ${ }^{47}$

\section{$D$. discoideum chemotaxis}

Finally, chemotaxis of $D$. discoideum amoebae up $\mathrm{Ca}^{2+}$ gradients has been demonstrated using microfluidic chambers. ${ }^{5}$ D. discoideum underwent chemotaxis in gradients in which $10 \mathrm{mM} \mathrm{Ca}^{2+}$ was at the source, roughly the same concentration effective in the source well of Boyden chambers for a number of cell types (Table 6). A parallel gradient

Table 6 Chemotaxis to cations

\begin{tabular}{|c|c|c|c|c|}
\hline Cell type & Cation & Optimal concentration & Methods & References \\
\hline Human MDA-MB-23I MCF7 & $\mathrm{Ca}^{2+}$ & $5 \mathrm{mM}$ & Boyden chamber and scratch wound assay & 47 \\
\hline Human monocytes & $\mathrm{Ca}^{2+}$ & $5 \mathrm{mM}$ & Boyden chamber & 39 \\
\hline Human monocytes & $\mathrm{Ca}^{2+}$ & $3-10 \mathrm{mM}$ & Boyden chamber & 40 \\
\hline Murine hematopoietic stem cells & $\mathrm{Ca}^{2+}$ & $\mathrm{n} / \mathrm{a}$ & $\begin{array}{l}\text { In vivo engraftment of } \mathrm{CaR}^{-1-} \text { cells into } \\
\text { wild-type mice }\end{array}$ & 36 \\
\hline Rat bone marrow endothial progenitor cells & $\mathrm{Ca}^{2+}$ & $3-10 \mathrm{mM}$ & Boyden chamber & 35 \\
\hline Murine RAW 264.7 & $\mathrm{Ca}^{2+}$ & $10 \mathrm{mM}$ & Boyden chamber & 43 \\
\hline Murine monocytes & $\mathrm{Ca}^{2+}$ & $5 \mathrm{mM}$ & Boyden chamber & 39 \\
\hline Murine monocytes & $\mathrm{Ca}^{2+}$ & $5 \mathrm{mM}$ & $\begin{array}{l}\text { In vivo injection of } \mathrm{Ca}^{2+} \text { and subsequent } \\
\text { quantitation of infiltrating monocytes }\end{array}$ & 39 \\
\hline Murine GnRH neurons & $\mathrm{Ca}^{2+}$ & $7.5 \mathrm{mM}$ & Boyden chamber & 42 \\
\hline Murine macrophage derived foam cells & $\mathrm{Ca}^{2+}$ & $\mathrm{I} \mathrm{mM}$ & Boyden chamber & 135 \\
\hline Murine macrophages & $\mathrm{Ca}^{2+}$ & $\mathrm{I} \mathrm{mM}$ & Boyden chamber & 135 \\
\hline Murine MC3T3-EI Osteoblast-like & $\mathrm{Ca}^{2+}$ & $5 \mathrm{mM}$ & Boyden chamber & 38 \\
\hline Murine MC3T3-EI Osteoblast-like & $\mathrm{Ca}^{2+}$ & $3-10 \mathrm{mM}$ & Boyden chamber & 40 \\
\hline Murine MC3T3-EI Osteoblast-like & $\mathrm{Ca}^{2+}$ & $4.8 \mathrm{mM}$ & Boyden chamber & 326 \\
\hline Dictyostelium discoideum & $\mathrm{Ca}^{2+}$ & $10 \mathrm{mM}$ & Microfluidic chamber & 5 \\
\hline Bracken fern spermatozoids & $\mathrm{Ca}^{2+}$ & $2.5 \mathrm{mM}$ & Capillary & 48 \\
\hline HUVEC & $\mathrm{Mg}^{2+}$ & $10 \mathrm{mM}$ & Boyden chamber & 44 \\
\hline Rat bone marrow endothial progenitor cells & $\mathrm{Mg}^{2+}$ & $10 \mathrm{mM}$ & Boyden chamber & 35 \\
\hline
\end{tabular}

Abbreviations: HUVEC, human umbilical vein endothelial cells; GnRH, gonadotropin-releasing hormone; $\mathrm{CaR}^{2} \mathrm{Ca}^{2+}$ receptor. 
of the chemoattractant cAMP enhanced chemotaxis in a $\mathrm{Ca}^{2+}$ gradient, the same result obtained with monocytes in parallel gradients of $\mathrm{Ca}^{2+}$ and MCP- $1 .{ }^{39}$ An opposing gradient of cAMP overrode chemotaxis to $\mathrm{Ca}^{2+}$, suggesting that a cAMP gradient presented a stronger chemotactic signal than a $\mathrm{Ca}^{2+}$ gradient. $^{5} \mathrm{~A}$ high global cAMP signal has been shown to induce the release of $\mathrm{Ca}^{2+}$, suggesting that as cAMP is released through a population, it causes a transient, coordinated release of $\mathrm{Ca}^{2+}$ and the formation of transient $\mathrm{Ca}^{2+}$ gradients. $\mathrm{Ca}^{2+}$ may function as a second chemoattractant that finetunes cellular movement in the front of each cAMP wave. ${ }^{5}$ The fact that many of the animal cell types that undergo chemotaxis to $\mathrm{Ca}^{2+}$ also undergo chemotaxis to cell typespecific signals raises the possibility that $\mathrm{Ca}^{2+}$ chemotaxis is ancient and conserved, and that cell types have added other cell type-specific chemotaxis systems later in evolution. ${ }^{5}$ In contrast with the results on $\mathrm{Ca}^{2+}$ chemotaxis, there are no definitive studies demonstrating that monovalent cations serve as chemoattractants, rather than simply chemokinetic agents, for animal cells. Attempts to obtain chemotaxis up $\mathrm{K}^{+}$ gradients with $D$. discoideum using microfluidic chambers have failed (unpublished data). However, these failures do not exclude the possibility that monovalent cation gradients exist, that chemotaxis to these gradients occurs, and that they occur through monovalent cation receptors.

\section{Conclusion}

It is hoped that this review will engender an interest in the possibility that in addition to sources of intracellular cations, extracellular cations may play roles as signals in cell motility, polarity, and chemotaxis. Cations have the potential to interact with plasma membrane proteins, which in turn activate signal transduction pathways, other membrane proteins, or the cytoskeleton. There is no question that $\mathrm{Ca}^{2+}$ plays such a role. We have reviewed just how different the extracellular cationic milieu is for the biota of different organisms and cell types within an organism, and emphasized that organism and cell type must have adapted to these cationic environments. We have also reviewed the literature demonstrating that $\mathrm{Ca}^{2+}$ gradients direct chemotaxis through bona fide cation receptors.

Because many of the surface molecules that transport cations must interact with the cations, we believe they represent easy targets to which signaling events could have been coupled during evolution. Hence, we would not be surprised to find that many cationic transporters, exchangers, and channels, upon cationic interaction, regulate other molecular processes through direct interaction. Hopefully, this review will heighten the awareness of such possibilities.

\section{Acknowledgments}

Work from the Soll Laboratory was funded by the Developmental Studies Hybridoma Bank and a gift from the Catholic Charitable Fund to the Monoclonal Antibody Research Institute through Mercy Medical Center, Des Moines, IA. We are grateful to Reginald Williams (Water Quality Laboratory, Public Utilities Dept, San Diego CA), Crystal Roldan and Craig Meacham (Iowa City Water Division, Iowa City, IA) for providing data for Table 1.

\section{Disclosure}

The authors report no conflicts of interest in this work.

\section{References}

1. Singer SJ, Kupfer A. The directed migration of eukaryotic cells. Annu Rev Cell Biol. 1986;2:337-365.

2. Soll DR, Wessels D, Kuhl S, Lusche DF. How a cell crawls and the role of cortical myosin II. Eukaryot Cell. 2009;8:1381-1396.

3. Lusche DF, Wessels D, Soll DR. The effects of extracellular calcium on motility, pseudopod and uropod formation, chemotaxis, and the cortical localization of myosin II in Dictyostelium discoideum. Cell Motil Cytoskeleton. 2009;66:567-587.

4. Lusche DF, Wessels D, Ryerson DE, Soll DR. Nhe1 is essential for potassium but not calcium facilitation of cell motility and the monovalent cation requirement for chemotactic orientation in Dictyostelium discoideum. Eukaryot Cell. 2011;10:320-331.

5. Scherer A, Kuhl S, Wessels D, Lusche DF, Raisley B, Soll DR. $\mathrm{Ca}^{2+}$ chemotaxis in Dictyostelium discoideum. J Cell Sci. 2010; 123(Pt 21):3756-3767.

6. Bray D. Cell Movements: From Molecules to Motility. 2nd ed. New York, NY: Garland Publishing; 2001.

7. Jin T, Hereld D, editors. Chemotaxis: Methods and Protocols. Totowa, NJ: Humana Press Inc; 2009.

8. Swaney KF, Huang CH, Devreotes PN. Eukaryotic chemotaxis: A network of signaling pathways controls motility, directional sensing, and polarity. Annu Rev Biophys. 2010;39:265-289.

9. Saeki S, Yamamoto M, Iino Y. Plasticity of chemotaxis revealed by paired presentation of a chemoattractant and starvation in the nematode Caenorhabditis elegans. J Exp Biol. 2001;204(Pt 10):1757-1764.

10. Breitwieser GE. Extracellular calcium as an integrator of tissue function. Int J Biochem Cell Biol. 2008;40:1467-1480.

11. Brown EM, MacLeod RJ. Extracellular calcium sensing and extracellular calcium signaling. Physiol Rev. 2001;81:239-297.

12. Case RM, Eisner D, Gurney A, Jones O, Muallem S, Verkhratsky A. Evolution of calcium homeostasis: From birth of the first cell to an omnipresent signalling system. Cell Calcium. 2007;42:345-350.

13. Arino J, Ramos J, Sychrova H. Alkali metal cation transport and homeostasis in yeasts. Microbiol Mol Biol Rev. 2010;74:95-120.

14. Galloway E, Doughty L. Electrolyte emergences and acute renal failure in pediactric critical care. Clin Pediatr Emerg Med. 2007;8:176-189.

15. Komendantov A, Cressman J, Barreto E. Ion concentration homeostasis and the regulation of neuronal firing activity: The role of cation-chloride cotransporters. BMC Neuroscience. 2010;11 Suppl 1:27.

16. Pinsky M, Brochard L, Mancebo J. Applied Physiology in Intensive Care Medicine. 2nd ed. Berlin: Springer; 2009.

17. Orlowski J, Grinstein S. Emerging roles of alkali cation/proton exchangers in organellar homeostasis. Curr Opin Cell Biol. 2007;19: 483-492.

18. Kurosaki T, Baba Y. Ca ${ }^{2+}$ signaling and STIM1.Prog Biophys Mol Biol. 2010;103:51-58. 
19. Hurwitz S. Homeostatic control of plasma calcium concentration. Crit Rev Biochem Mol Biol. 1996;31:41-100.

20. Schwab A, Nechyporuk-Zloy V, Fabian A, Stock C. Cells move when ions and water flow. Pflugers Arch. 2007;453:421-432.

21. Orlov SN, Hamet P. Intracellular monovalent ions as second messengers. J Membr Biol. 2006;210:161-172.

22. McCarthy T, Kumar R. Divalent cation metabloism: Magnesium. In: Berl T, editor. Atlas of the Diseases of the Kidney Section 1. Disorders of Water, Electrolytes, and Acid Base. Vol 1. Boston, MA: Wiley-Blackwell; 1999.

23. Baartscheer A, van Borren MM. Sodium ion transporters as new therapeutic targets in heart failure. Cardiovasc Hematol Agents Med Chem. 2008;6:229-236.

24. Ringer S. Concerning the influence exerted by each of the constituents of the blood on the contraction of the ventricle. J Physiol. 1882;3:380-393.

25. Ringer S. A further contribution regarding the influence of the different constituents of the blood on the contraction of the heart. J Physiol. $1883 ; 4: 29-42.3$.

26. Ringer S. A third contribution regarding the influence of the inorganic constituents of the blood on the ventricular contraction. J Physiol. $1883 ; 4: 222-225$.

27. Ringer S. Regarding the effect of the saline ingredients of the blood on the contraction of the heart. Br Med J. 1885;1:731-734.

28. Ringer S. Regarding the action of lime potassium and sodium salts on skeletal muscle. J Physiol. 1887;8:20-24.

29. Baskett TF. The resuscitation greats: Sydney ringer and lactated Ringer's solution. Resuscitation. 2003;58:5-7.

30. Kees MG, Schlotterbeck H, Passemard R, Pottecher T, Diemunsch P. Ringer solution: Osmolarity and composition revisited. Ann Fr Anesth Reanim. 2005;24:653-655. French.

31. Brown EM, Gamba G, Riccardi D, et al. Cloning and characterization of an extracellular $\mathrm{Ca}^{2+}$-sensing receptor from bovine parathyroid. Nature. 1993;366:575-580.

32. Khan MA, Conigrave AD. Mechanisms of multimodal sensing by extracellular $\mathrm{Ca}(2+)$-sensing receptors: A domain-based survey of requirements for binding and signalling. Br J Pharmacol. 2010;159: 1039-1050.

33. Stock C, Schwab A. Protons make tumor cells move like clockwork. Pflugers Arch. 2009;458:981-992.

34. Schwab A, Hanley P, Fabian A, Stock C. Potassium channels keep mobile cells on the go. Physiology (Bethesda). 2008;23:212-220.

35. Aguirre A, Gonzalez A, Planell JA, Engel E. Extracellular calcium modulates in vitro bone marrow-derived flk- $1^{+} \mathrm{CD} 34^{+}$progenitor cell chemotaxis and differentiation through a calcium-sensing receptor. Biochem Biophys Res Commun. 2010;393:156-161.

36. Adams GB, Chabner KT, Alley IR, et al. Stem cell engraftment at the endosteal niche is specified by the calcium-sensing receptor. Nature. 2006;439:599-603.

37. Reitz RE, Daane TA, Woods JR, Weinstein RL. Calcium, magnesium, phosphorus, and parathyroid hormone interrelationships in pregnancy and newborn infants. Obstet Gynecol. 1977;50:701-705.

38. Godwin SL, Soltoff SP. Extracellular calcium and platelet-derived growth factor promote receptor-mediated chemotaxis in osteoblasts through different signaling pathways. J Biol Chem. 1997;272:11307-11312.

39. Olszak IT, Poznansky MC, Evans RH, et al. Extracellular calcium elicits a chemokinetic response from monocytes in vitro and in vivo. J Clin Invest. 2000;105:1299-1305.

40. Sugimoto T, Kanatani M, Kano J, et al. Effects of high calcium concentration on the functions and interactions of osteoblastic cells and monocytes and on the formation of osteoclast-like cells. J Bone Miner Res. 1993;8:1445-1452.

41. Menon GK, Grayson S, Elias PM. Ionic calcium reservoirs in mammalian epidermis: Ultrastructural localization by ion-capture cytochemistry. J Invest Dermatol. 1985;84: $508-512$.
42. Chattopadhyay N, Jeong KH, Yano S, et al. Calcium receptor stimulates chemotaxis and secretion of MCP-1 in GnRH neurons in vitro: Potential impact on reduced GnRH neuron population in CaR-null mice. Am J Physiol Endocrinol Metab. 2007;292: E523-E532.

43. Boudot C, Saidak Z, Boulanouar AK, et al. Implication of the calcium sensing receptor and the phosphoinositide 3-kinase/Akt pathway in the extracellular calcium-mediated migration of RAW 264.7 osteoclast precursor cells. Bone. 2010;46:1416-1423.

44. Lapidos KA, Woodhouse EC, Kohn EC, Masiero L. Mg(++)-induced endothelial cell migration: Substratum selectivity and receptorinvolvement. Angiogenesis. 2001;4:21-28.

45. Liao J, Schneider A, Datta NS, McCauley LK. Extracellular calcium as a candidate mediator of prostate cancer skeletal metastasis. Cancer Res. 2006;66:9065-9073.

46. Morris VL, Chan BM. Interaction of epidermal growth factor, $\mathrm{Ca}^{2+}$, and matrix metalloproteinase-9 in primary keratinocyte migration. Wound Repair Regen. 2007;15:907-915.

47. Saidak Z, Boudot C, Abdoune R, et al. Extracellular calcium promotes the migration of breast cancer cells through the activation of the calcium sensing receptor. Exp Cell Res. 2009;315:2072-2080.

48. Brokaw CJ. Calcium and flagellar response during the chemotaxis of bracken spermatozoids. J Cell Physiol. 1974;83:151-158.

49. Quarles LD, Hartle JE 2nd, Siddhanti SR, Guo R, Hinson TK. A distinct cation-sensing mechanism in MC3T3-E1 osteoblasts functionally related to the calcium receptor. J Bone Miner Res. 1997;12: 393-402.

50. Willey JM, Waterbury JB, Greenberg EP. Sodium-coupled motility in a swimming cyanobacterium. J Bacteriol. 1987;169: 3429-3434.

51. Cox P. The Elements their Origin, Abundance, and Distribution. Oxford: Oxford University Press; 1989.

52. Goldberg E, Broecker W, Gross M, Turekian K. Marine chemistry. In: Radioactivity in the Marine Environment. Washington, DC: National Academy of Sciences; 1971.

53. Gross M. Oceanography. A View of the Earth. Englewood Cliffs, NJ: Prentice-Hall Inc; 1971.

54. Lapresta-Fernandez A, Huertas R, Melgosa M, Capitan-Vallvey L. Multianalyte imaging in one-shot format sensors for natural waters. Anal Chim Acta. 2009;636:210-217.

55. Millero F. Chemical Oceanography. 3rd ed. Boca Raton, FL: CRC Press; 2006.

56. Turekian K. Oceans. 2nd ed. Englewood Cliffs, NJ: Prentice-Hall Inc; 1976.

57. Williams RJP, Frausto Da Silva JJ. Evolution was chemically constrained. J Theor Biol. 2003;220:323-343.

58. Williams RJP, da Silva JJR. The trinity of life: The genome, the proteome, and the mineral chemical elements. J Chem. 2004;81:738-749.

59. Komiya T, Takafumi H, Kitajima K, et al. Evolution of the composition of seawater through geologic time, and its influence on the evolution of life. Gondwana Research. 2008;14:159-174.

60. Aloisi G. The calcium carbonate saturation state in cyanobacterial mats throughout earth's history. Geochim Cosmochim Acta. 2008;72: 6037-6060.

61. Sharma M, Shukla Y. The evolution and distribution of life in the Precambrian eon - global perspective and the Indian record. J Bio Sci. 2009;34:765-776.

62. Dawson $\mathrm{G}$. Ionic composition of rain during sixteen convective showers. Atmos Environ. 1977;12:1991-1999.

63. McCormick SD, Regish AM, Christensen AK. Distinct freshwater and seawater isoforms of $\mathrm{Na}^{+} / \mathrm{K}^{+}$-ATPase in gill chloride cells of Atlantic salmon. J Exp Biol. 2009;212(Pt 24):3994-4001.

64. Tipsmark CK, Luckenbach JA, Madsen SS, Borski RJ. IGF-I and branchial IGF receptor expression and localization during salinity acclimation in striped bass. Am J Physiol Regul Integr Comp Physiol. 2007;292:R535-R543. 
65. Singer T, Clements K, Semple J, et al. Seawater tolerance and gene expression in two strains of Atlantic salmon smolts. Can J Fish Aquat Sci. 2002;59:125-135.

66. Hoar W. The physiology of smolting salmonids. In: Fish Physiology. Vol 11 (Part B). New York, NY: Academic Press; 1988.

67. Pelis RM, McCormick SD. Effects of growth hormone and cortisol on $\mathrm{Na}^{(+)}-\mathrm{K}^{(+)}-2 \mathrm{Cl}^{(-)}$cotransporter localization and abundance in the gills of Atlantic salmon. Gen Comp Endocrinol. 2001;124:134-143.

68. Pelis RM, Zydlewski J, McCormick SD. Gill Na(+)-K(+)-2Cl(-) cotransporter abundance and location in Atlantic salmon: Effects of seawater and smolting. Am J Physiol Regul Integr Comp Physiol. 2001;280:R1844-R1852.

69. Morris A, Mantoura R, Bale A, Howland R. Very low salinity regions of estuaries: Important sites for chemical and biological reactions. Nature. 1978;274:678-680.

70. Muylaert K, Sabbe K, Vyverman W. Changes in phytoplankton diversity and community composition along the salinity gradient of the schelde estuary (Belgium/The Netherlands). Estuar Coast Shelf Sci. 2009;82:335-340.

71. Tipsmark CK, Sorensen KJ, Hulgard K, Madsen SS. Claudin-15 and -25 b expression in the intestinal tract of Atlantic salmon in response to seawater acclimation, smoltification and hormone treatment. Comp Biochem Physiol A Mol Integr Physiol. 2010;155:361-370.

72. Hagemann M. Molecular biology of cyanobacterial salt acclimation. FEMS Microbiol Rev. 2011:87-123.

73. Shapiguzov A, Lyukevich AA, Allakhverdiev SI, et al. Osmotic shrinkage of cells of synechocystis sp. PCC 6803 by water efflux via aquaporins regulates osmostress-inducible gene expression. Microbiology. 2005;151(Pt 2):447-455.

74. Jentsch TJ. CLC chloride channels and transporters: From genes to protein structure, pathology and physiology. Crit Rev Biochem Mol Biol. 2008;43:3-36.

75. Mikkat S, Hagemann M. Molecular analysis of the ggtBCD gene cluster of Synechocystis sp. strain PCC6803 encoding subunits of an ABC transporter for osmoprotective compounds. Arch Microbiol. 2000;174:273-282.

76. Wang HL, Postier BL, Burnap RL. Polymerase chain reaction-based mutageneses identify key transporters belonging to multigene families involved in $\mathrm{Na}^{+}$and $\mathrm{pH}$ homeostasis of Synechocystis sp. PCC 6803 Mol Microbiol. 2002;44:1493-1506.

77. Adams F. Ionic concentrations and activities in soil solutions. Soil Sci Soc Am J. 1971;35:420-426.

78. Bangerth F. Calcium-related physiological disorders of plants. Annu Rev Phytopathol. 1979;17:97-122.

79. Fried M, Shapiro R. Soil-plant relationships in ion uptake. Annu Rev Plant Physiol. 1961;12:91-112.

80. Lindsay W. Chemical Equilibria in Soils. New York, NY: John Wiley and Sons; 1926.

81. McLaughlin SB, Wimmer R. Tansley Review No. 104. Calcium Physiology and Terrestrial Ecosystem Processes. Cambridge, UK: Cambridge University Press; 1999.

82. Kilmer V, Younts S, Brady N. The Role of Potassium in Agriculture. Madison, WI: American Society of Agronomy; 1968.

83. Bonner J. The Social Amoebae: The Biology of Cellular Slime Molds/ John Tyler Bonner. Princeton, NJ: Princeton University Press; 2009.

84. Schaap P. Evolutionary crossroads in developmental biology: Dictyostelium discoideum. Development. 2011;138:387-396.

85. Sanchez C. Microbial genetics: Social amoebae get ready for sex. Nat Rev Microbiol. 2011;9:79.

86. Li SI, Purugganan MD. The cooperative amoeba: Dictyostelium as a model for social evolution. Trends Genet. 2011;27:48-54.

87. Escalante R. Dictyostelium as a model for human disease. Semin Cell Dev Biol. 2011;22:69.

88. Bloomfield G, Skelton J, Ivens A, Tanaka Y, Kay RR. Sex determination in the social amoeba Dictyostelium discoideum. Science. 2010;330:1533-1536.
89. Van Haastert PJ. A model for a correlated random walk based on the ordered extension of pseudopodia. PLoS Comput Biol. 2010;6:8.

90. Fuller D, Chen W, Adler M, et al. External and internal constraints on eukaryotic chemotaxis. Proc Natl Acad Sci U S A. 2010;107: 9656-9659.

91. Barry NP, Bretscher MS. Dictyostelium amoebae and neutrophils can swim. Proc Natl Acad Sci U S A. 2010;107:11376-11380.

92. Gilbert OM, Queller DC, Strassmann JE. Discovery of a large clonal patch of a social amoeba: Implications for social evolution. Mol Ecol. 2009; 18:1273-1281.

93. Brefeld O. Dictyostelium mucoroides. Ein neuer organismus aus der verwandtschaft der myxomyceten. Abhandlungen der Senckenbergischen Naturforschenden Gesellschaft Frankfurt. 1869;7:85-107.

94. Thom C, Raper KB. Myxamoebae in soil and decomposing crop residues. J Wash Acad Sci. 1930;20:362-370.

95. Raper KB. Dictyostelium discoideum, a new species of slime mold from decaying forest leaves. J Agric Res. 1935;50:135-147.

96. Sathe S, Kaushik S, Lalremruata A, Aggarwal RK, Cavender JC, Nanjundiah V. Genetic heterogeneity in wild isolates of cellular slime mold social groups. Microb Ecol. 2010;60:137-148.

97. Brock DA, Douglas TE, Queller DC, Strassmann JE. Primitive agriculture in a social amoeba. Nature. 2011;469:393-396.

98. Vadell EM, Cavender JC, Romeralo M, Edwards SM, Stephenson SL, Baldauf SL. New species of dictyostelids from Patagonia and Tierra del Fuego, Argentina. Mycologia. 2010;103:101-117.

99. Morton HJ. A survey of commercially available tissue culture media. In Vitro. 1970;6:89-108.

100. Moore GE, Gerner RE, Franklin HA. Culture of normal human leukocytes. JAMA. 1967;199:519-524.

101. Moore GE, Hood DB. Modified RPMI 1640 culture medium. In Vitro Cell Dev Biol Anim. 1993;29 A:268.

102. Eagle H. Amino acid metabolism in mammalian cell cultures. Science. 1959; 130:432-437.

103. Fogh-Andersen N, Altura BM, Altura BT, Siggaard-Andersen O. Composition of interstitial fluid. Clin Chem. 1995;41:1522-1525.

104. Silver IA, Murrills RJ, Etherington DJ. Microelectrode studies on the acid microenvironment beneath adherent macrophages and osteoclasts. Exp Cell Res. 1988;175:266-276.

105. Janle E, Cregor M, Sojka J. Interstitial fluid calcium, magnesium and phosphorus concentrations in bone, muscle and subcutaneous tissue sampled with ultrafiltration probes. Curr Sep. 2001;19:81-85.

106. Dvorak MM, Siddiqua A, Ward DT, et al. Physiological changes in extracellular calcium concentration directly control osteoblast function in the absence of calciotropic hormones. Proc Natl Acad Sci U S A 2004;101:5140-5145.

107. Habel B, Glaser R. Human osteoblast-like cells respond not only to the extracellular calcium concentration but also to its changing rate. Eur Biophys J. 1998;27:411-416.

108. Tsai JA, Bucht E, Torring O, Kindmark H. Extracellular calcium increases free cytoplasmic calcium and DNA synthesis in human osteoblasts. Horm Metab Res. 2004;36:22-26.

109. Evans KJ, Greenberg A. Hyperkalemia: A review. J Intensive Care Med. 2005;20:272-290.

110. Liang CZ, Zhang XJ, Wang DB, Hao ZY, Lv LY. Measurement of electrolyte concentrations in expressed prostatic secretion and urine from patients with chronic prostatitis and its implications. Arch Androl. 2006;52:29-34.

111. Pellitteri PK. Evaluation of hypercalcemia in relation to hyperparathyroidism. Otolaryngol Clin North Am. 2010;43:389-397, x.

112. Goldfarb M, O’Neal P, Shih JL, Hartzband P, Connolly J, Hasselgren PO. Synchronous parathyroid carcinoma, parathyroid adenoma, and papillary thyroid carcinoma in a patient with severe and long-standing hyperparathyroidism. Endocr Pract. 2009;15: 463-468.

113. Hamed SA, Abdellah MM, El-Melegy N. Blood levels of trace elements, electrolytes, and oxidative stress/antioxidant systems in epileptic patients. J Pharmacol Sci. 2004;96:465-473. 
114. Romarís EM, Cervantes II, López JM, Marcén JF. Concentration of calcium and magnesium and trace elements (zinc, copper, iron and manganese) in cerebrospinal fluid: A try of a pathophysiological classification. JTrace Elem Med Biol. December 10, 2010. [Epub ahead of print].

115. Touyz RM. Magnesium in clinical medicine. Front Biosci. 2004;9: 1278-1293.

116. Busch W, Saier MH Jr. The transporter classification (TC) system, 2002. Crit Rev Biochem Mol Biol. 2002;37:287-337.

117. Busch W, Saier MH Jr. The IUBMB-endorsed transporter classification system. Mol Biotechnol. 2004;27:253-262.

118. Saier MH Jr, Yen MR, Noto K, Tamang DG, Elkan C. The transporter classification database: Recent advances. Nucleic Acids Res. 2009;37: D274-D278.

119. Kubalski A, Martinac B. Bacterial Ion Channels and their Eukaryotic Homologs. Washington, DC: American Society for Microbiology Press; 2005.

120. Konrad M, Weber S. Recent advances in molecular genetics of hereditary magnesium-losing disorders. J Am Soc Nephrol. 2003;14:249-260.

121. Riccardi D, Finney BA, Wilkinson WJ, Kemp PJ. Novel regulatory aspects of the extracellular $\mathrm{Ca}^{2+}$-sensing receptor, CaR. Pflugers Arch. 2009;458:1007-1022.

122. Titze J, Machnik A. Sodium sensing in the interstitium and relationship to hypertension. Curr Opin Nephrol Hypertens. 2010;19:385-392.

123. Berridge MJ. Calcium signalling and Alzheimer's disease. Neurochem Res. December 24, 2010. [Epub ahead of print].

124. Deng X, Wang Y, Zhou Y, Soboloff J, Gill DL. STIM and Orai: Dynamic intermembrane coupling to control cellular calcium signals. J Biol Chem. 2009;284:22501-22505.

125. Berkefeld H, Fakler B, Schulte U. Ca2+-activated K+ channels: From protein complexes to function. Physiol Rev. 2010;90:1437-1459.

126. Lehman W, Szent-Gyorgyi AG. Regulation of muscular contraction. Distribution of actin control and myosin control in the animal kingdom. J Gen Physiol. 1975;66:1-30.

127. Kaeser PS, Deng L, Wang Y, et al. RIM proteins tether $\mathrm{Ca}(2+)$ channels to presynaptic active zones via a direct PDZ-domain interaction. Cell. 2011;144:282-295.

128. Garrett JE, Capuano IV, Hammerland LG, et al. Molecular cloning and functional expression of human parathyroid calcium receptor cDNAs. J Biol Chem. 1995;270:12919-12925.

129. Hendy GN, D’Souza-Li L, Yang B, Canaff L, Cole DE. Mutations of the calcium-sensing receptor (CASR) in familial hypocalciuric hypercalcemia, neonatal severe hyperparathyroidism, and autosomal dominant hypocalcemia. Hum Mutat. 2000;16:281-296.

130. Hu J, Spiegel AM. Naturally occurring mutations of the extracellular $\mathrm{Ca}^{2+}$-sensing receptor: Implications for its structure and function. Trends Endocrinol Metab. 2003;14:282-288.

131. Hannan FM, Nesbit MA, Christie PT, et al. A homozygous inactivating calcium-sensing receptor mutation, Pro339Thr, is associated with isolated primary hyperparathyroidism: Correlation between location of mutations and severity of hypercalcaemia. Clin Endocrinol (Oxf). 2010;73:715-722.

132. Dong Q, Cheng Z, Chang W, et al. Naturally-occurring mutation in the calcium-sensing receptor reveals the significance of extracellular domain loop III region for class C G-protein-coupled receptor function. J Clin Endocrinol Metab. 2010;95:E245-E252.

133. Magno AL, Ward BK, Ratajczak T. The calcium-sensing receptor: A molecular perspective. Endocr Rev. 2011;32:3-30.

134. Bandyopadhyay S, Jeong KH, Hansen JT, Vassilev PM, Brown EM, Chattopadhyay N. Calcium-sensing receptor stimulates secretion of an interferon-gamma-induced monokine (CXCL10) and monocyte chemoattractant protein-3 in immortalized GnRH neurons. J Neurosci Res. 2007;85:882-895

135. Shi H, Severs NJ, Robenek H. Effects of calcium on the migration and recruitment of macrophages and macrophage-derived foam cells. FASEB J. 1996;10:491-501.
136. Rondard P, Goudet C, Kniazeff J, Pin JP, Prezeau L. The complexity of their activation mechanism opens new possibilities for the modulation of mGlu and GABAB class $\mathrm{C} G$ protein-coupled receptors. Neuropharmacology. 2010;60:82-92.

137. MacLeod RJ, Yano S, Chattopadhyay N, Brown EM. Extracellular calcium-sensing receptor transactivates the epidermal growth factor receptor by a triple-membrane-spanning signaling mechanism. Biochem Biophys Res Commun. 2004;320:455-460.

138. Huang Y, Zhou Y, Yang W, et al. Identification and dissection of $\mathrm{Ca}(2+)$-binding sites in the extracellular domain of $\mathrm{Ca}(2+)$-sensing receptor. J Biol Chem. 2007;282:19000-19010.

139. Bai M. Structure-function relationship of the extracellular calciumsensing receptor. Cell Calcium. 2004;35:197-207.

140. Huang Y, Zhou Y, Castiblanco A, Yang W, Brown EM, Yang JJ. Multiple $\mathrm{Ca}^{2+}$-binding sites in the extracellular domain of the $\mathrm{Ca}^{2+}$-sensing receptor corresponding to cooperative $\mathrm{Ca}^{2+}$ response. Biochemistry. 2009;48:388-398.

141. Quinn SJ, Ye CP, Diaz R, et al. The $\mathrm{Ca}^{2+}$-sensing receptor: A target for polyamines. Am J Physiol. 1997;273(4 Pt 1):C1315-C1323.

142. Quinn SJ, Bai M, Brown EM. pH sensing by the calcium-sensing receptor. J Biol Chem. 2004;279:37241-37249.

143. Chang W, Pratt S, Chen TH, Bourguignon L, Shoback D. Amino acids in the cytoplasmic $\mathrm{C}$ terminus of the parathyroid $\mathrm{Ca}^{2+}$-sensing receptor mediate efficient cell-surface expression and phospholipase C activation. J Biol Chem. 2001;276:44129-44136.

144. Yi S, Sahni N, Daniels KJ, Pujol C, Srikantha T, Soll DR. The same receptor, $\mathrm{G}$ protein, and mitogen-activated protein kinase pathway activate different downstream regulators in the alternative white and opaque pheromone responses of Candida albicans. Mol Biol Cell. 2008;19:957-970.

145. Yi S, Sahni N, Pujol C, et al. A Candida albicans-specific region of the alpha-pheromone receptor plays a selective role in the white cell pheromone response. Mol Microbiol. 2009;71:925-947.

146. Chang W, Chen TH, Pratt S, Shoback D. Amino acids in the second and third intracellular loops of the parathyroid $\mathrm{Ca}^{2+}$-sensing receptor mediate efficient coupling to phospholipase C. J Biol Chem. 2000;275:19955-19963.

147. De Jesus Ferreira MC, Helies-Toussaint C, Imbert-Teboul M, et al. Co-expression of a $\mathrm{Ca}^{2+}$-inhibitable adenylyl cyclase and of a $\mathrm{Ca}^{2+}$ sensing receptor in the cortical thick ascending limb cell of the rat kidney. Inhibition of hormone-dependent cAMP accumulation by extracellular $\mathrm{Ca}^{2+}$. J Biol Chem. 1998;273:15192-15202.

148. Huang C, Handlogten ME, Miller RT. Parallel activation of phosphatidylinositol 4-kinase and phospholipase $\mathrm{C}$ by the extracellular calcium-sensing receptor. J Biol Chem. 2002;277: 20293-20300.

149. Huang C, Hujer KM, Wu Z, Miller RT. The $\mathrm{Ca}^{2+}$-sensing receptor couples to Galpha12/13 to activate phospholipase D in MadinDarby canine kidney cells. Am J Physiol Cell Physiol. 2004;286: C22-C30.

150. Ray K, Hauschild BC, Steinbach PJ, Goldsmith PK, Hauache O, Spiegel AM. Identification of the cysteine residues in the aminoterminal extracellular domain of the human $\mathrm{Ca}(2+)$ receptor critical for dimerization. Implications for function of monomeric $\mathrm{Ca}(2+)$ receptor. J Biol Chem. 1999;274:27642-27650.

151. Awata H, Huang C, Handlogten ME, Miller RT. Interaction of the calcium-sensing receptor and filamin, a potential scaffolding protein. J Biol Chem. 2001;276:34871-34879.

152. Hjalm G, MacLeod RJ, Kifor O, Chattopadhyay N, Brown EM. Filamin-A binds to the carboxyl-terminal tail of the calciumsensing receptor, an interaction that participates in CaR-mediated activation of mitogen-activated protein kinase. J Biol Chem. 2001;276:34880-34887.

153. Handlogten ME, Huang C, Shiraishi N, Awata H, Miller RT. The $\mathrm{Ca}^{2+}$-sensing receptor activates cytosolic phospholipase A2 via a gqalpha-dependent ERK-independent pathway. J Biol Chem. 2001;276:13941-13948. 
154. Ward DT. Calcium receptor-mediated intracellular signalling. Cell Calcium. 2004;35:217-228.

155. Maiti A, Hait NC, Beckman MJ. Extracellular calcium-sensing receptor activation induces vitamin $\mathrm{D}$ receptor levels in proximal kidney HK-2G cells by a mechanism that requires phosphorylation of p38alpha MAPK. J Biol Chem. 2008;283:175-183.

156. Montell C, Rubin GM. Molecular characterization of the Drosophila trp locus: A putative integral membrane protein required for phototransduction. Neuron. 1989;2:1313-1323.

157. Cosens DJ, Manning A. Abnormal electroretinogram from a Drosophila mutant. Nature. 1969;224:285-287.

158. Minke B, Wu C, Pak WL. Induction of photoreceptor voltage noise in the dark in Drosophila mutant. Nature. 1975;258:84-87.

159. Hardie RC. TRP channels and lipids: From Drosophila to mammalian physiology. J Physiol. 2007;578(Pt 1):9-24.

160. Vannier B, Zhu X, Brown D, Birnbaumer L. The membrane topology of human transient receptor potential 3 as inferred from glycosylationscanning mutagenesis and epitope immunocytochemistry. J Biol Chem. 1998;273:8675-8679.

161. Reaves BJ, Wolstenholme AJ. The TRP channel superfamily: Insights into how structure, protein-lipid interactions and localization influence function. Biochem Soc Trans. 2007;35(Pt 1):77-80.

162. Song MY, Yuan JX. Introduction to TRP channels: Structure, function, and regulation. Adv Exp Med Biol. 2010;661:99-108.

163. Oberwinkler J, Lis A, Giehl KM, Flockerzi V, Philipp SE. Alternative splicing switches the divalent cation selectivity of TRPM3 channels. J Biol Chem. 2005;280:22540-22548.

164. Kraft R, Harteneck C. The mammalian melastatin-related transient receptor potential cation channels: An overview. Pflugers Arch. 2005;451:204-211.

165. Furuichi T, Yoshikawa S, Miyawaki A, Wada K, Maeda N, Mikoshiba K. Primary structure and functional expression of the inositol 1,4,5-trisphosphate-binding protein P400. Nature. 1989;342:32-38.

166. Yule DI, Betzenhauser MJ, Joseph SK. Linking structure to function: Recent lessons from inositol 1,4,5-trisphosphate receptor mutagenesis. Cell Calcium. 2010;47:469-479.

167. Mourey RJ, Estevez VA, Marecek JF, Barrow RK, Prestwich GD, Snyder SH. Inositol 1,4,5-trisphosphate receptors: Labeling the inositol 1,4,5-trisphosphate binding site with photoaffinity ligands. Biochemistry. 1993;32:1719-1726.

168. Joseph SK. The inositol triphosphate receptor family. Cell Signal. $1996 ; 8: 1-7$

169. Sienaert I, Nadif Kasri N, Vanlingen S, et al. Localization and function of a calmodulin-apocalmodulin-binding domain in the N-terminal part of the type 1 inositol 1,4,5-trisphosphate receptor. Biochem $J$. 2002;365(Pt 1):269-277.

170. Foskett JK, White C, Cheung KH, Mak DO. Inositol trisphosphate receptor $\mathrm{Ca}^{2+}$ release channels Physiol Rev. 2007;87:593-658.

171. Dellis O, Dedos SG, Tovey SC, Taufiq Ur R, Dubel SJ, Taylor CW. $\mathrm{Ca}^{2+}$ entry through plasma membrane IP3 receptors. Science. 2006;313: 229-233.

172. Rossier MF, Bird GS, Putney JW Jr. Subcellular distribution of the calcium-storing inositol 1,4,5-trisphosphate-sensitive organelle in rat liver. Possible linkage to the plasma membrane through the actin microfilaments. Biochem J. 1991;274(Pt 3):643-650.

173. Fadool DA, Ache BW. Inositol 1,3,4,5-tetrakisphosphate-gated channels interact with inositol 1,4,5-trisphosphate-gated channels in olfactory receptor neurons. Proc Natl Acad Sci U S A. 1994;91:9471-9475.

174. Traynor D, Milne JL, Insall RH, Kay RR. $\mathrm{Ca}\left({ }^{2+}\right)$ signalling is not required for chemotaxis in Dictyostelium. EMBO J. 2000;19:4846-4854.

175. Schaloske RH, Lusche DF, Bezares-Roder K, Happle K, Malchow D, Schlatterer C. $\mathrm{Ca}^{2+}$ regulation in the absence of the iplA gene product in Dictyostelium discoideum. BMC Cell Biol. 2005;6:13.

176. Fache S, Dalous J, Engelund M, et al. Calcium mobilization stimulates Dictyostelium discoideum shear-flow-induced cell motility. J Cell Sci. 2005;118:3445-3457.
177. Kubokawa K, Miyashita T, Nagasawa H, Kubo Y. Cloning and characterization of a bifunctional metabotropic receptor activated by both extracellular calcium and glutamate. FEBS Lett. 1996;392:71-76.

178. Kubo Y, Miyashita T, Murata Y. Structural basis for a $\mathrm{Ca}^{2+}$ sensing function of the metabotropic glutamate receptors. Science. 1998;279:1722-1725.

179. Tabata T, Kano M. Calcium dependence of native metabotropic glutamate receptor signaling in central neurons. Mol Neurobiol. 2004;29:261-270.

180. Galvez T, Prezeau L, Milioti G, et al. Mapping the agonist-binding site of GABAB type 1 subunit sheds light on the activation process of GABA B receptors. J Biol Chem. 2000;275:41166-41174.

181. Patel H, Barber DL. A developmentally regulated $\mathrm{Na}-\mathrm{H}$ exchanger in Dictyostelium discoideum is necessary for cell polarity during chemotaxis. J Cell Biol. 2005;169:321-329.

182. Patel MK, Clunn GF, Lymn JS, Austin O, Hughes AD. Effect of serum withdrawal on the contribution of L-type calcium channels (CaV1.2) to intracellular $\mathrm{Ca}^{2+}$ responses and chemotaxis in cultured human vascular smooth muscle cells. Br J Pharmacol. 2005;145:811-817.

183. Brett CL, Donowitz M, Rao R. Evolutionary origins of eukaryotic sodium $/ \mathrm{H}^{+}$exchangers. Am J Physiol Cell Physiol. 2005;288:C223-C239.

184. Chang AB, Lin R, Keith Studley W, Tran CV, Saier MH Jr. Phylogeny as a guide to structure and function of membrane transport proteins. Mol Membr Biol. 2004;21:171-181.

185. Guan XM, Kobilka TS, Kobilka BK. Enhancement of membrane insertion and function in a Type IIIb membrane protein following introduction of a cleavable signal peptide. J Biol Chem. 1992;267: 21995-21998.

186. Brennan SC, Conigrave AD. Regulation of cellular signal transduction pathways by the extracellular calcium-sensing receptor. Curr Pharm Biotechnol. 2009;10:270-281.

187. Rhoads DB, Waters FB, Epstein W. Cation transport in Escherichia coli. VIII. Potassium transport mutants. J Gen Physiol. 1976;67: 325-341.

188. Booth IR, Epstein W, Giffard PM, Rowland GC. Roles of the trkB and trkC gene products of Escherichia coli in $\mathrm{K}^{+}$transport. Biochimie. 1985;67:83-89.

189. Fujisawa M, Ito M, Krulwich TA. Three two-component transporters with channel-like properties have monovalent cation $/ \mathrm{H}^{+}$antiport activity. Proc Natl Acad Sci U S A. 2007;104:13289-13294.

190. Day JP, Wan S, Allan AK, et al. Identification of two partners from the bacterial Kef exchanger family for the apical plasma membrane V-ATPase of metazoa. J Cell Sci. 2008;121(Pt 15):2612-2619.

191. Wickner W, Schekman R. Protein translocation across biological membranes. Science. 2005;310:1452-1456.

192. Alken M, Schmidt A, Rutz C, et al. The sequence after the signal peptide of the $\mathrm{G}$ protein-coupled endothelin $\mathrm{B}$ receptor is required for efficient translocon gating at the endoplasmic reticulum membrane. Mol Pharmacol. 2009;75:801-811.

193. Robertson HM, Thomas JH. The putative chemoreceptor families of C. elegans. WormBook. 2006:1-12.

194. Thomas JH, Robertson HM. The Caenorhabditis chemoreceptor gene families. BMC Biol. 2008;6:42.

195. Kracun S, Chaptal V, Abramson J, Khakh BS. Gated access to the pore of a P2X receptor: Structural implications for closed-open transitions. J Biol Chem. 2010;285:10110-10121.

196. Bocquet N, Prado de Carvalho L, Cartaud J, et al. A prokaryotic proton-gated ion channel from the nicotinic acetylcholine receptor family. Nature. 2007;445:116-119.

197. Sine SM, Engel AG. Recent advances in cys-loop receptor structure and function. Nature. 2006;440:448-455.

198. Chen GQ, Cui C, Mayer ML, Gouaux E. Functional characterization of a potassium-selective prokaryotic glutamate receptor. Nature. 1999;402:817-821.

199. Chaudhry C, Plested AJ, Schuck P, Mayer ML. Energetics of glutamate receptor ligand binding domain dimer assembly are modulated by allosteric ions. Proc Natl Acad Sci U S A. 2009;106:12329-12334. 
200. Furukawa H, Singh SK, Mancusso R, Gouaux E. Subunit arrangement and function in NMDA receptors. Nature. 2005;438: 185-192.

201. Pin JP, Galvez T, Prezeau L. Evolution, structure, and activation mechanism of family 3/C G-protein-coupled receptors. Pharmacol Ther. 2003;98:325-354.

202. Taniura H, Sanada N, Kuramoto N, Yoneda Y. A metabotropic glutamate receptor family gene in Dictyostelium discoideum. J Biol Chem. 2006;281:12336-12343.

203. Fountain SJ, Burnstock G. An evolutionary history of P2X receptors. Purinergic Signal. 2009;5:269-272.

204. Fountain SJ. Neurotransmitter receptor homologues of Dictyostelium discoideum. J Mol Neurosci. 2010;41:263-266.

205. Grzesiak JJ, Pierschbacher MD. Shifts in the concentrations of magnesium and calcium in early porcine and rat wound fluids activate the cell migratory response. J Clin Invest. 1995;95:227-233.

206. Gail MH, Boone CW, Thompson CS. A calcium requirement for fibroblast motility and proliferation. Exp Cell Res. 1973;79: 386-390.

207. Harkin DG, Bignold LP. Importance of extracellular divalent cations to polarisation of polymorphonuclear leukocytes induced by plasma. Cell Biol Int Rep. 1990;14:1099-1107.

208. Hennings H, Holbrook KA. Calcium regulation of cell-cell contact and differentiation of epidermal cells in culture. An ultrastructural study. Exp Cell Res. 1983;143:127-142.

209. Lagunes R, Ruiz L, Frixione E. Contraction of epithelial (MDCK) cells in response to low extracellular calcium is dependent on extracellular sodium. J Muscle Res Cell Motil. 1999;20:761-770.

210. Volk AP, Heise CK, Hougen JL, et al. ClC-3 and IClswell are required for normal neutrophil chemotaxis and shape change. $J$ Biol Chem. 2008;283:34315-34326.

211. Heiner I, Eisfeld J, Luckhoff A. Role and regulation of TRP channels in neutrophil granulocytes. Cell Calcium. 2003;33: 533-540.

212. Heiner I, Radukina N, Eisfeld J, Kuhn F, Luckhoff A. Regulation of TRPM2 channels in neutrophil granulocytes by ADP-ribose: A promising pharmacological target. Naunyn Schmiedebergs Arch Pharmacol. 2005;371:325-333.

213. Kindzelskii AL, Sitrin RG, Petty HR. Cutting edge: Optical microspectrophotometry supports the existence of gel phase lipid rafts at the lamellipodium of neutrophils: Apparent role in calcium signaling. J Immunol. 2004;172:4681-4685.

214. Ritter M, Schratzberger P, Rossmann H, et al. Effect of inhibitors of $\mathrm{Na}+/ \mathrm{H}+$-exchange and gastric $\mathrm{H}+/ \mathrm{K}+$ ATPase on cell volume, intracellular $\mathrm{pH}$ and migration of human polymorphonuclear leucocytes Br J Pharmacol. 1998;124:627-638.

215. Fukushima T, Waddell TK, Grinstein S, Goss GG, Orlowski J, Downey GP. $\mathrm{Na}^{+} / \mathrm{H}^{+}$exchange activity during phagocytosis in human neutrophils: Role of fcgamma receptors and tyrosine kinases. $J$ Cell Biol. 1996;132:1037-1052.

216. Marks PW, Maxfield FR. Transient increases in cytosolic free calcium appear to be required for the migration of adherent human neutrophils. J Cell Biol. 1990;110:43-52.

217. Yumura S, Furuya K, Takeuchi I. Intracellular free calcium responses during chemotaxis of Dictyostelium cells. J Cell Sci. 1996; 109(Pt 11):2673-2678.

218. deHart GW, Jin T, McCloskey DE, Pegg AE, Sheppard D. The alpha9betal integrin enhances cell migration by polyamine-mediated modulation of an inward-rectifier potassium channel. Proc Natl Acad Sci USA. 2008;105:7188-7193.

219. Reid G, Babes A, Pluteanu F. A cold- and menthol-activated current in rat dorsal root ganglion neurones: Properties and role in cold transduction. $J$ Physiol. 2002;545(Pt 2):595-614.

220. Bidaux G, Flourakis M, Thebault S, et al. Prostate cell differentiation status determines transient receptor potential melastatin member 8 channel subcellular localization and function. J Clin Invest. 2007;117:1647-1657.
221. Tsavaler L, Shapero MH, Morkowski S, Laus R. Trp-p8, a novel prostate-specific gene, is up-regulated in prostate cancer and other malignancies and shares high homology with transient receptor potential calcium channel proteins. Cancer Res. 2001;61:3760-3769.

222. Zhang L, Barritt GJ. TRPM8 in prostate cancer cells: A potential diagnostic and prognostic marker with a secretory function? Endocr Relat Cancer. 2006;13:27-38.

223. Gkika D, Flourakis M, Lemonnier L, Prevarskaya N. PSA reduces prostate cancer cell motility by stimulating TRPM 8 activity and plasma membrane expression. Oncogene. 2010;29:4611-4616.

224. Prevarskaya N, Skryma R, Shuba Y. Ion channels and the hallmarks of cancer. Trends Mol Med. 2010;16:107-121.

225. Diaz D, Delgadillo DM, Hernandez-Gallegos E, et al. Functional expression of voltage-gated sodium channels in primary cultures of human cervical cancer. $J$ Cell Physiol. 2007;210:469-478.

226. Sontheimer $H$. An unexpected role for ion channels in brain tumor metastasis. Exp Biol Med (Maywood). 2008;233:779-791.

227. Lin CY, Huang TP. Enhancement of ionized calcium and 1,25dihydroxycholecalciferol loss from peritoneal fluid during peritonitis in patients treated with continuous ambulatory peritoneal dialysis. Nephron. 1991;59:90-95.

228. Kaslick RS, Chasens AI, Mandel ID, et al. Sodium, potassium and calcium in gingival fluid: A study of the relationship of the ions to one another, to circadian rhythms, gingival bleeding, purulence, and to conservative periodontal therapy. J Periodontol. 1970;41:442-448.

229. Lillie R, Mason J. Limnological charateristics of Wisconsin lakes. Technical Bulletin Series 138. Madison WI Department of Natural Resources and US Department of Interior. Washington DC, 2007.

230. Lim DSS, Douglas MSV. Limnological characteristics of 22 lakes and ponds in the Haughton crater region of Devon Island, Nunavut, Canadian high arctic. Arctic, Antarctic, and Alpine Research. 2003;35: 509-519.

231. Palik B, Batzer D, Buech R, et al. Seasonal pond characteristics across a chronosequence of adjacent forest ages in Northern Minnesota, USA. Wetlands. 2001;21:532-542.

232. Potapova M, Charles D. Distribution of benthice diatoms in US rivers in relation to conductivity and ionic composition. Freshw Biol. 2003;48:1311-1328.

233. Rozanska A, Wisniewski J. Modification of brackish water composition by means of Donnan dialysis as pretreatment before desalination. Desalination. 2006;200:615-617.

234. Ben Silk M, Mnif A, Hamrouni B, Dhahbi M. Electrodialytic desalination of brackish water: Effect of process parameters and water characteristics. Ionics. 2010;16:621-629.

235. Rodrigues F, Garcia S, Corro R, et al. Analisis de las aguas embotelladas y de grifo espanolas y de las implicaciones de su consumo en la litiasis urinaria. Actas Urol Esp. 2009;33:778-793.

236. Angle JS, McGrath SP, Chaney RL. New culture medium containing ionic concentrations of nutrients similar to concentrations found in the soil solution. Appl Environ Microbiol. 1991;57:3674-3676.

237. Hao C, Chang C. Effect of 25 annual cattle manure applications on soluble and exchangeable cations in soil. Soil Sci. 2002;167:126-134.

238. Haynes R, Judge A. Influence of surface-applied poultry manure on topsoil and subsoil acidity and salinity: A leaching column study. J Plant Nutr Soil Sci. 2008;171:370-377.

239. Qian P, Schoenau JJ, King T, Japp M. Effect of repeated manure application on potassium, calcium and magnesium in soil and cereal crops in Sakatchewan. Canadian Journal of Soil Science. 2005;85:397-403.

240. Morr S, Cuartas E, Alwattar B, Lane J. How much calcium is in your drinking water? A survey of calcium concentrations in bottled and tap water and their significance for medical treatment and drug administration. HSS J. 2006;2:130-135.

241. Gardner RS. The use of tricine buffer in animal tissue cultures. $J$ Cell Biol. 1969;42:320-321.

242. Sussman M. Cultivation and synchronous morphogenesis of Dictyostelium under controlled experimental conditions. Methods Cell Biol. 1987;28:9-29. 
243. Bolourani P, Spiegelman GB, Weeks G. Delineation of the roles played by RasG and RasC in cAMP-dependent signal transduction during the early development of Dictyostelium discoideum. Mol Biol Cell. 2006; 17:4543-4550.

244. Bonner JT. Evidence for the formation of cell aggregates by chemotaxis in the development of the slime mold Dictyostelium discoideum. J Exp Zool. 1947;106:1-26.

245. Chen L, Iijima M, Tang M, et al. PLA2 and PI3K/PTEN pathways act in parallel to mediate chemotaxis. Dev Cell. 2007;12:603-614.

246. Marin FT, Rothman FG. Regulation of development in Dictyostelium discoideum. IV. Effects of ions on the rate of differentiation and cellular response to cyclic AMP. J Cell Biol. 1980;87(3 Pt 1):823-827.

247. Gerisch G, Luderitz O, Ruschmann E. Antibodies promoting phagocytosis of bacteria by amoebae. Z Naturforsch B. 1967;22:109. German.

248. King JS, Teo R, Ryves J, et al. The mood stabiliser lithium suppresses PIP3 signalling in Dictyostelium and human cells. Dis Model Mech. 2009;2:306-312.

249. Bosgraaf L, Van Haastert PJ, Bretschneider T. Analysis of cell movement by simultaneous quantification of local membrane displacement and fluorescent intensities using Quimp2. Cell Motil Cytoskeleton. 2009;66:156-165.

250. McCann CP, Kriebel PW, Parent CA, Losert W. Cell speed, persistence and information transmission during signal relay and collective migration. J Cell Sci. 2010;123(Pt 10):1724-1731.

251. Cassidy SL, Henry JA, Roberts AM. Determination of membranestabilizing potency of drugs by video analysis of protozoan motility. Toxicol In Vitro. 1989;3:181-187.

252. Wu C, Fry CH, Henry JA. Membrane toxicity of opioids measured by protozoan motility. Toxicology. 1997;117:35-44.

253. Holz G Jr, Erwin J, Rosenbaum N, Aaronson S. Triparanol inhibition of tetrahymena, and its prevention by lipids. Arch Biochem Biophys. 1962;98:312-322.

254. Neff R. Purification, axenic cultivation and description of a soil amoeba, Acanthamoeba sp. J Protozool. 1957;4:176-182.

255. Bruce DL, Marshall MJ Jr. Some ionic and bioelectric properties of the ameba Chaos chaos. J Gen Physiol. 1965;49:151-178.

256. Tang O, Almsheriqi Z, Debg Y. A simple mass culture of amoebae Chaos carolinense: revisit. Protistology. 2005;4:185-190.

257. Band RN. Nutritional and related biological studies on the freeliving soil amoeba, Hartmannella rhysodes. J Gen Microbiol. 1959;21:80-95

258. Pringsheim E. Die kultur von micrasterias und volvox. Arch f Protist. 1930;72:1-48.

259. Starr R. The culture collection of algae at Indiana University. Am J Bot. 1964;51:1013-1044.

260. University of Texas at Austin. UTEX The Culture Collection of Algae. Austin, TX. Available at: http://www.Sbs.Utexas.edu/utex/. Accessed March 6, 2011.

261. Waris H. The significance for algae of chelating substances in nutrient solution. Physiol Plant. 1953;6:538-543.

262. Brennand H, Soars N, Dworjanyn S, Davis A, Byrne M. Impact of ocean warming and ocean acidification on larval development and calcification in the sea urchin Tripneustes gratilla. Plos One. 2010;5:1-7.

263. Benson S, Smith L, Wilt F, Shaw R. The synthesis and secretion of collagen by cultured sea urchin micromeres. Exp Cell Res. 1990;188:141-146.

264. Ettensohn C, Wessel G, Wray G. Development of Sea Urchins, Ascidians, and Other Deuterostomes: Experimental Approaches. London: Academic Press; 2004.

265. Harrison P, Berges J. Marine culture media. In: Andersen R, editor. Algal Culturing Techniques. London: Academic Press; 2005.

266. Strathmann M. Reproduction and Development of Marine Invertrebrates of the Northern Pacific Coast. Seattle, WA: University of Washington Press; 1987.

267. Eppig JJ, Dumont JN. Defined nutrient medium for the in vitro maintenance of Xenopus laevis oocytes. In Vitro. 1976;12:418-427.
268. Laub LB, Jones BD, Powell WH. Responsiveness of a Xenopus laevis cell line to the aryl hydrocarbon receptor ligands 6-formylindolo[3,2-b] carbazole (FICZ) and 2,3,7,8-tetrachlorodibenzo-p-dioxin (TCDD). Chem Biol Interact. 2010;183:202-211.

269. Morgan JF, Morton HJ, Parker RC. Nutrition of animal cells in tissue culture: Initial studies on a synthetic medium. Proc Soc Exp Biol Med. 1950;73:1-8.

270. Morton HJ, Tolnai S. Preparation of medium 199. Methods Cell Sci. 1978;4:729-736.

271. Lockart RJ, Eagle H. Requirements for growth of single human cells. Science. 1959;129:252-254.

272. Guan W, He X, Li L, et al. Establishment and biological characterization of fibroblast cell line from the Langshan chicken. Cell Prolif. 2010;43:157-163.

273. Miller DJ. Sydney Ringer; physiological saline, calcium and the contraction of the heart. J Physiol. 2004;555(Pt 3):585-587.

274. Leibovitz A. The growth and maintenance of tissue-cell cultures in free gas exchange with the atmosphere. Am J Hyg. 1963;78:173-180.

275. Bronner F. Extracellular and intracellular regulation of calcium homeostasis. Scientific World Journal. 2001;1:919-925.

276. Darrow DC. Body-fluid physiology: The relation of tissue composition to problems of water and electrolyte balance. $N$ Engl J Med. 1945;233:91-97.

277. Kaim W, Schwederski B. Bioorganic Chemistry: Inorganic Elements in the Chemistry of Life: An Introduction and Guide. Chichester, UK: John Wiley and Sons; 1991.

278. Moe SM. Disorders involving calcium, phosphorus, and magnesium. Prim Care. 2008:35:215-37, v-vi.

279. Rousselet F, Durlach J. Techniques analytiques et explorations practiques du metabolisme magnesique en clinique humaine. In: Durlacj J, editor. Ier Symposium International Sur Le Deficit Magnesique En Pathologie Humaine. Vol 1. SGEMV, Vittel, Franca; 1971:65-90.

280. Shutskaya Z, Shakhmatova E, Kuznetsova A, Natochin Y. The role of the kidneys in the regulation of osmolality and concentrations of cations in the blood serum in hyperglycemia. Hum Physiol. 2008;34: 73-79.

281. Consolazio CF, Matoush LO, Nelson RA, Harding RS, Canham JE. Excretion of sodium, potassium, magnesium and iron in human sweat and the relation of each to balance and requirements. J Nutr. 1963;79: 407-415

282. Paunier L, Girardin E, Sizonenko PG, Wyss M, Megevand A. Calcium and magnesium concentration in sweat of normal children and patients with cystic fibrosis. Pediatrics. 1973;52:446-448.

283. Lear RD, Gron P. Magnesium in human saliva. Arch Oral Biol. 1968;13:1311-1319.

284. Zipkin I, Bullock FA, Mantel N. The relation of salivary sodium, potassium, solids and ash concentration to dental caries experience in children, 5 to 6 and 12 to 14 years of age. J Dent Res. 1957;36: $525-531$.

285. Lindahl A, Ungell A, Knutson L, Lennernäs H. Characterization of fluids from the stomach and proximal jejunum in men and women. Pharm Res. 1997;14:497-502.

286. Grayson TL, White JE, Moyer CA. Oxygen consumptions; concentrations of inorganic ions in urine, serum and duodenal fluid, hematocrits, urinary excretions; pulse rates and blood pressure during duodenal depletions of sodium salts in normal and alcoholic man. Ann Surg. 1963;158:840-858.

287. Hansky J. Calcium content of duodenal juice. Am J Dig Dis. 1967;12: 725-733.

288. Miyata S, Toyoshima M, Inada M, Takashima M, Itokawa Y. Metal contents in duodenal aspirates of normal subjects during pancreozymin-secretin test. Gastroenterol Jpn. 1982;17:207-213.

289. Perez AV, Picotto G, Carpentieri AR, Rivoira MA, Peralta Lopez ME, Tolosa de Talamoni NG. Minireview on regulation of intestinal calcium absorption. Emphasis on molecular mechanisms of transcellular pathway. Digestion. 2008;77:22-34. 
290. Stevens T, Conwell DL, Zuccaro G, et al. Electrolyte composition of endoscopically collected duodenal drainage fluid after synthetic porcine secretin stimulation in healthy subjects. Gastrointest Endosc. 2004;60:351-355.

291. Wasserman RH. Vitamin D and the dual processes of intestinal calcium absorption. J Nutr. 2004;134:3137-3139.

292. Yamada M, Alpers D, Laine L, Owyang C, Powell D, editors. Textbook of Gastroenterology. 4th ed. Philadelphia, PA: Lippincott Williams \& Wilkins; 2003.

293. Brannan PG, Vergne-Marini P, Pak CY, Hull AR, Fordtran JS. Magnesium absorption in the human small intestine. Results in normal subjects, patients with chronic renal disease, and patients with absorptive hypercalciuria. J Clin Invest. 1976;57:1412-1418.

294. Sladen G. Conservation of fluid and electrolytes by the human gut. J Clin Pathol. 1971;24:99-107.

295. Kavanagh JP. Sodium, potassium, calcium, magnesium, zinc, citrate and chloride content of human prostatic and seminal fluid. J Reprod Fertil. 1985;75:35-41.

296. Valtin H. Renal Function: Mechanisms Preserving Fluid and Electrolyte Balance in Health. Boston, MA: Little Brown; 1983.

297. Csenker E, Dioszeghy P, Fekete I, Mechler F. Ion concentrations in serum and cerebrospinal fluid of patients with neuromuscular diseases. Arch Psychiatr Nervenkr. 1982;231:251-258. German.

298. Somjen GG. Extracellular potassium in the mammalian central nervous system. Annu Rev Physiol. 1979;41:159-177.

299. Brand JS, Cushing J, Hefley T. Potassium, sodium, and the intracellular fluid space of cells from bone. Calcif Tissue Int. 1979;29:119-125.

300. Rubinacci A, Benelli FD, Borgo E, Villa I. Bone as an ion exchange system: Evidence for a pump-leak mechanism devoted to the maintenance of high bone $\mathrm{K}(+)$. Am J Physiol Endocrinol Metab. 2000;278:E15-E24.

301. Scarpace PJ, Neuman WF. The blood: Bone disequilibrium. I. The active accumulation of $\mathrm{K}^{+}$into the bone extracellular fluid. Calcif Tissue Res. 1976:137-149.

302. Albuquerque CA, Nijland MJ, Ross MG. Human and ovine amniotic fluid composition differences: Implications for fluid dynamics. J Matern Fetal Med. 1999;8:123-129.

303. Anastasiadis P, Atassi S, Rimpler M. The concentration of the elements $\mathrm{Zn}, \mathrm{Cu}, \mathrm{Mg}, \mathrm{Fe}, \mathrm{Na}, \mathrm{K}$ in human amniotic fluid during birth. J Perinat Med. 1981;9:228-234.

304. Johnell HE, Nilsson BA. Oxygen tension, acid-base status and electrolytes in human amniotic fluid. Acta Obstet Gynecol Scand. 1971;50: 183-192.

305. Roland W, Meyerhoff W. Hearing Loss. New York, NY: Thieme Medical Publishers Inc; 1996.

306. Wangemann P, Schacht J. Homeostasic mechanisms in the cochlea. In: Dallos P, Popper A, Fay R, editors. Handbook of Auditory Research: The Cochlea. Berlin: Springer; 1996.

307. Fernandez C. Biochemistry of labyrinthine fluids. Inorganic substances. Arch Otolaryngol. 1967;86:222-233.

308. Chong AP, Taymor ML, Lechene CP. Electron probe microanalysis of the chemical elemental content of human follicular fluid. Am J Obstet Gynecol. 1977;128:209-211.

309. Cajori F, Crouter C, Pemberton R. The physiology of synovial fluid. Arch Intern Med. 1926;37:92-101.
310. Krachler M, Domej W, Irgolic KJ. Concentrations of trace elements in osteoarthritic knee-joint effusions. Biol Trace Elem Res. 2000;75: 253-263.

311. Chhaparwal BC, Mehta S, Singh SD. Magnesium levels in serum, erythrocytes and urine in protein calorie malnutrition. Indian J Pediatr. 1971;38:162-171.

312. Holt C. Interrelationships of the concentrations of some ionic constituents of human milk and comparison with cow and goat milks. Comp Biochem Physiol Comp Physiol. 1993;104:35-41.

313. Milara J, Mata M, Serrano A, Peiro T, Morcillo EJ, Cortijo J. Extracellular calcium-sensing receptor mediates human bronchial epithelial wound repair. Biochem Pharmacol. 2010;80:236-246.

314. Cox JL, Lancaster T, Carlson CG. Changes in the motility of B16F10 melanoma cells induced by alterations in resting calcium influx. Melanoma Res. 2002;12:211-219.

315. Young LG, Nelson L. Calcium ions and control of the motility of sea urchin spermatozoa. J Reprod Fertil. 1974;41:371-378.

316. Pitta TP, Sherwood EE, Kobel AM, Berg HC. Calcium is required for swimming by the nonflagellated cyanobacterium synechococcus strain WH8113. J Bacteriol. 1997;179:2524-2528.

317. Banai S, Haggroth L, Epstein SE, Casscells W. Influence of extracellular magnesium on capillary endothelial cell proliferation and migration. Circ Res. 1990;67:645-650.

318. Wong PY, Lee WM, Tsang AY. The effects of extracellular sodium on acid release and motility initiation in rat caudal epididymal spermatozoa in vitro. Exp Cell Res. 1981;131:97-104.

319. Atsumi T, McCarter L, Imae Y. Polar and lateral flagellar motors of marine vibrio are driven by different ion-motive forces. Nature. 1992; 355:182-184.

320. Kojima S, Yamamoto K, Kawagishi I, Homma M. The polar flagellar motor of Vibrio cholerae is driven by an $\mathrm{Na}+$ motive force. J Bacteriol. 1999;181:1927-1930.

321. Kita-Tsukamoto K, Wada M, Yao K, Nishino T, Kogure K. Flagellar motors of marine bacteria halomonas are driven by both protons and sodium ions. Can J Microbiol. 2004;50:369-374.

322. Levite M, Cahalon L, Peretz A, et al. Extracellular $\mathrm{K}(+)$ and opening of voltage-gated potassium channels activate $\mathrm{T}$ cell integrin function: Physical and functional association between Kv1.3 channels and beta1 integrins. J Exp Med. 2000;191:1167-1176.

323. Roberts RL, Mounessa NL, Gallin JI. Increasing extracellular potassium causes calcium-dependent shape change and facilitates concanavalin A capping in human neutrophils. J Immunol. 1984;132:2000-2006.

324. Datta HK, MacIntyre I, Zaidi M. The effect of extracellular calcium elevation on morphology and function of isolated rat osteoclasts. Biosci Rep. 1989;9:747-751.

325. Zhang A, Cheng TP, Altura BM. Magnesium regulates intracellular free ionized calcium concentration and cell geometry in vascular smooth muscle cells. Biochim Biophys Acta. 1992;1134:25-29.

326. Yamaguchi T, Chattopadhyay N, Kifor O, Butters RR Jr, Sugimoto T, Brown EM. Mouse osteoblastic cell line (MC3T3-E1) expresses extracellular calcium $(\mathrm{Ca} 2+\mathrm{o})$-sensing receptor and its agonists stimulate chemotaxis and proliferation of MC3T3-E1 cells. J Bone Miner Res. 1998;13:1530-1538.
Research and Reports in Biology

\section{Publish your work in this journal}

Research and Reports in Biology is an international, peer-reviewed, open access journal publishing original research, reports, editorials, reviews and commentaries on all areas of biology including animal biology, biochemical biology, cell biology, ecological studies, evolutionary biology, molecular biology, plant science and botany. The

\section{Dovepress}

manuscript management system is completely online and includes a very quick and fair peer-review system. Visit http://www.dovepress. com/testimonials.php to read real quotes from published authors. 